\title{
Soil Geomorphology of Garpanchkot Hill Area and Its Influence on Land Use and Land Cover
}

\author{
Arindam Sarkar ${ }^{1,2}$ \\ ${ }^{1}$ Department of Geography, P.K.H.N. College, Howrah, India \\ ${ }^{2}$ Department of Geography, University of Calcutta, Kolkata, India \\ Email: arindam.srkr1@gmail.com
}

How to cite this paper: Sarkar, A. (2019). Soil Geomorphology of Garpanchkot Hill Area and Its Influence on Land Use and Land Cover. Journal of Geoscience and Environment Protection, 7, 108-135.

https://doi.org/10.4236/gep.2019.77009

Received: May 13, 2019

Accepted: July 23, 2019

Published: July 26, 2019

Copyright $\odot 2019$ by author(s) and Scientific Research Publishing Inc. This work is licensed under the Creative Commons Attribution International License (CC BY 4.0).

http://creativecommons.org/licenses/by/4.0/

c) (i) Open Access

\begin{abstract}
The present study is about to find out different attributes of soil as well as geomorphology. It is very much relevant to the study of land use land cover (LULC). Garpanchkot hill is situated in Purulia district of West Bengal. There are two geomorphological and seven pedological parameters that have been selected for the study. Shuttle radar topographic mission (SRTM) and advanced land observing satellite (ALOS) data are analyzed by remote sensing software to find out the geomorphological character of the area. There are twenty soil samples that have been taken from top of the hill to foothill pediment area with the change of elevation and slope for laboratory analysis. Different statistical techniques are used for representation. Foot hill area of the Garpanchkot hill can be determined by less than $150 \mathrm{~m}$ elevation and $5^{\circ}$ slope. Elevation and slope of rest of the hill area (greater than $150 \mathrm{~m}$ and $5^{\circ}$ ) are fully dominated by forest and scattered vegetation. Elevated area (greater than $205 \mathrm{~m})$ with less slope $\left(10^{\circ}-15^{\circ}\right)$ is associated with dense forest. Escarpment area is associated with grass land and scattered vegetation. Foothill area is bearing the signature of scattered vegetation, bare soil ground and agriculture. The richness of clay minerals plays an important role in the foothill pediment area for development of agriculture. Sandy loam is dominating soil texture in the rest of the hill area. Percentage of organic matter (1.8\%), status of salinity $(6.65-7.72)$ and alkalinity (up to $138.6 \mu \mathrm{s} / \mathrm{cm}$ ) remain high in the high elevated area due to forest cover. The area is very dry, only fed by the rainfall during monsoon season. Artificial reservoir feeds the foothill agriculture system. Rice, wheat, maize, sugarcane, pulses chili and vegetables are the main crops of this area.
\end{abstract}

\section{Keywords}

Soil, Geomorphology, Foothill, Agriculture, Forest, Sandy Loam 


\section{Introduction}

Soil geomorphology is a scientific study of soil character according to the change of geomorphological parameters such as elevation and slope. Various landscape units have their different assemblage landforms as the unique expression of the surface of the earth shaped by works of different geomorphic process on the parent rock (Thornbury, 1954). Re-shaping of the geological surface produces residuals (Thomas, 1969). Those are playing an important and initial role in soil forming processes. Soil is produced from the parent rock (weathering residuals). Soil geomorphological evolution and characterization have great significance in land use (LU) and land cover (LC) pattern of the region (Chatterjee, 2005; Zinck, 2013). LU and LC characterization (Vats, 1988) of an area depends on geomorphological and pedological character (De, 1972; Conacher \& Dalrymple, 1977; Sarkar \& Das, 2018). Evolution and development of soil geomorphology as a new branch of geomorphology is associated with the emergence and blooming of geomorphology and pedology (Zinck et al., 2016) separately as two important branches of earth science (Tricart, 1965) by different eminent scholars. Primarily soil geomorphological research was subjected to build up on conceptual and methodological consideration. Pedological aspects in relation to the significance of geomorphological processes and landforms ware main focus to survey and mapping of pioneer scholars of soil geomorphology. It has been commented by some scholars of geomorphology of the nineteenth century that pedology is an important branch of geomorphology. In the year of 2003, soil geomorphology is considered as the scientific study of the processes of landscape evolution and its influence on soil formation and distribution on landscape (Goudie, 2003). Soil geomorphology is a pioneer methodological approach to soil inventory (Zinck et al., 2016). It can give us geomorphic analysis of soil distribution patterns. J. A. Zinck et al. (2016) noted that Geopedology (Soil geomorphology) deals with the relations between Geomorphology and Pedology. Change of climate affects earth natural system (Slaymaker \& Embleton-Hamann, 2009). Pedology can be considered as an important branch of geomorphology (Tricart, 1965). Formation and development of soil depend on geomorphological processes (Conacher \& Dalrymple, 1977) and systems. In this regards, soil and associated landforms become a new issue of research among the earth scientist. Establishment of interrelationship between geomorphology and pedology has become very important. Geomorphology deals with the land forming processes (Strahler, 1973; Selby, 1982; Sparks, 1986; Summerfield, 1991) where pedology deals with soil forming processes on landforms. Formation and development of soil depends on nature of landform (Jenny, 1930; Jenny, 1941; Kaley, 2007) Nature of soil depends on attributes and processes of geomorphology (Steila, 1976; Mehera, 2006; Lal, 2016). Scientific investigation of the evolution of landform and patterns of soil formation is possible only when interrelationship between geomorphology and soil is being recognized (Conacher \& Dalrymple, 1978; Gerrard, 1995; Mollay, 1998). Land is a natural resource. Utilization of land is done to get economic benefit and development of human life depending on its character (De, 1984a; Dey \& De, 1988). 
Land is composed of soil (De, 1984a; Dey \& De, 1988; De \& Sarkar, 1993). Nature and character of land depends on character of soil (Tan, 2008; Zong et al., 2012). Characteristics of soil depend on nature of landform and types of land forming process of that area (De, 1984b; De, 1987; De \& Chatterjee, 2009). So land use and land cover of an area depends on nature and properties of soil and geomorphological characteristics (De \& Chatterjee, 2009; Sarkar \& Das, 2018). Sustainable utilization of land resource is only possible when people understand about landform and soil character of inhabited surrounding area. Soil geomorphology is concern with relations between geomorphology and pedology. Both are considered as scientific discipline of earth science. It is inseparable from each other. "Tricart suggests that pedology ought to be a branch of geomorphology, for the reason pedology studies specific features of the phenomena taking place at the contact between lithosphere and atmosphere" (Zinck et al., 2016). Pioneer attempt has been done by Tricart (1965) to find out the relation between geomorphology and pedology. Soilgeomorphological analysis provides a good outcome for both pedological and geomorphological studies. It can be summarized and integrated as the research, regarding evolution and classification of land as a resource, the potentiality of land-water-biotic resource and its sustainability.

Present study is associated with consideration of some hypothesis regarding soil geomorphological study. Soil characteristics from top of the hill area to foothill pediment area will differ according to change of elevation and slope. Depth of soil will decrease as gradient increases. Depth of soil is limited with length of root of the plant. Soil moisture will decrease as gradient increases. Soil acidity will be the highest where gradient is the lowest in elevation. Soil texture will be sandier where slope gradient is the greatest and clay particles have been washed down-slope. Organic matter content will be the highest where slope gradient is the lowest and soil depth in the greatest. Soil acidity will be positively related to vegetation density, topography and morphology.

The objectives of the present research are to study the geomorphology and soil character and to establish relationship between soil character, slope and topography in the foothill area of Garpanchkot hill. The objectives have the potentiality to find out a way to establish the importance of the geomorphological attributes and their significance to the systematic study of Pedology. It is also needed to find out relation between soil geomorphological character and associated land use and land cover of the area. Combination of morphology and topography creates landforms. Landform and soil are closely interrelated. They have the major influence upon land potentiality. Land use and land cover system of an area depends on potentiality of the concerned land. Garpanchkot hill is situated at the south western boundary of Purulia district in West Bengal (Figure 1, Plate 1). Garpanchkot hill (Plate 1) covers 2.37 sq.km areas with maximum elevation of about $600 \mathrm{~m}$. Here 150-meter contour is considered as foothill boundary.

\section{Data and Methodology}

Present study can be broadly divided into three phases, as 1) pre-filed (preparation 


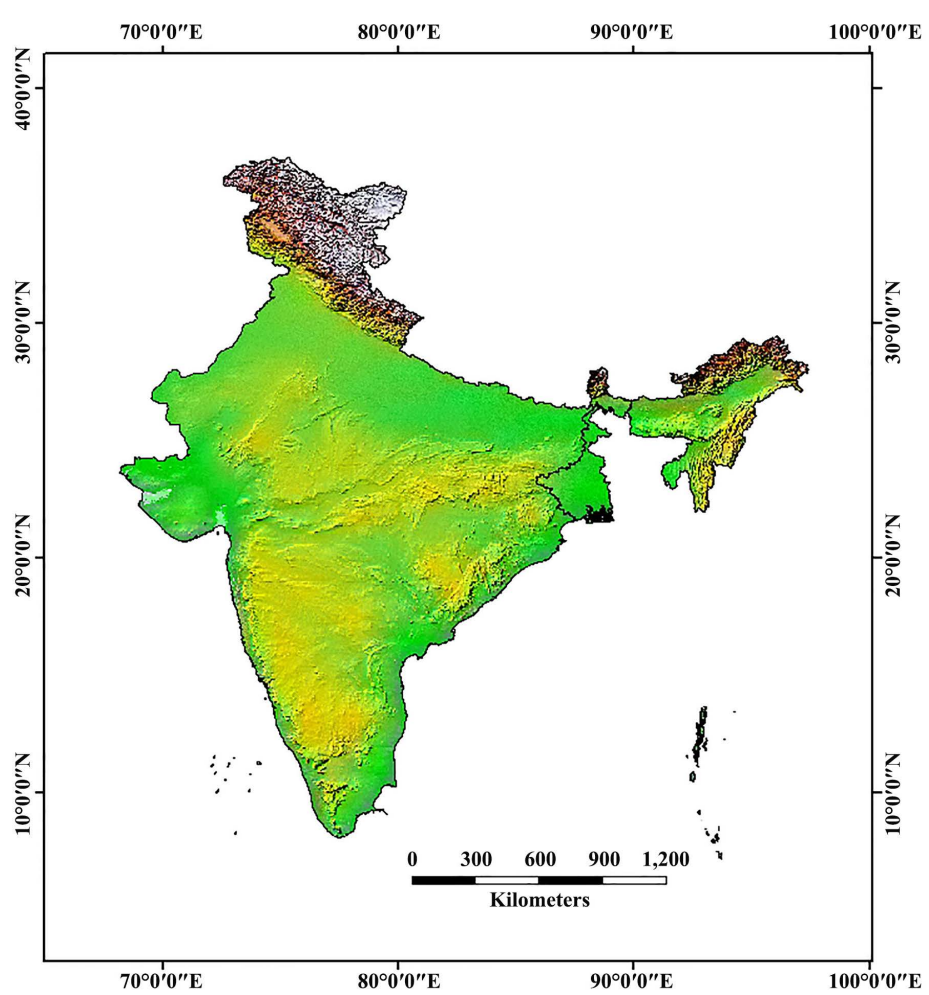

(a)

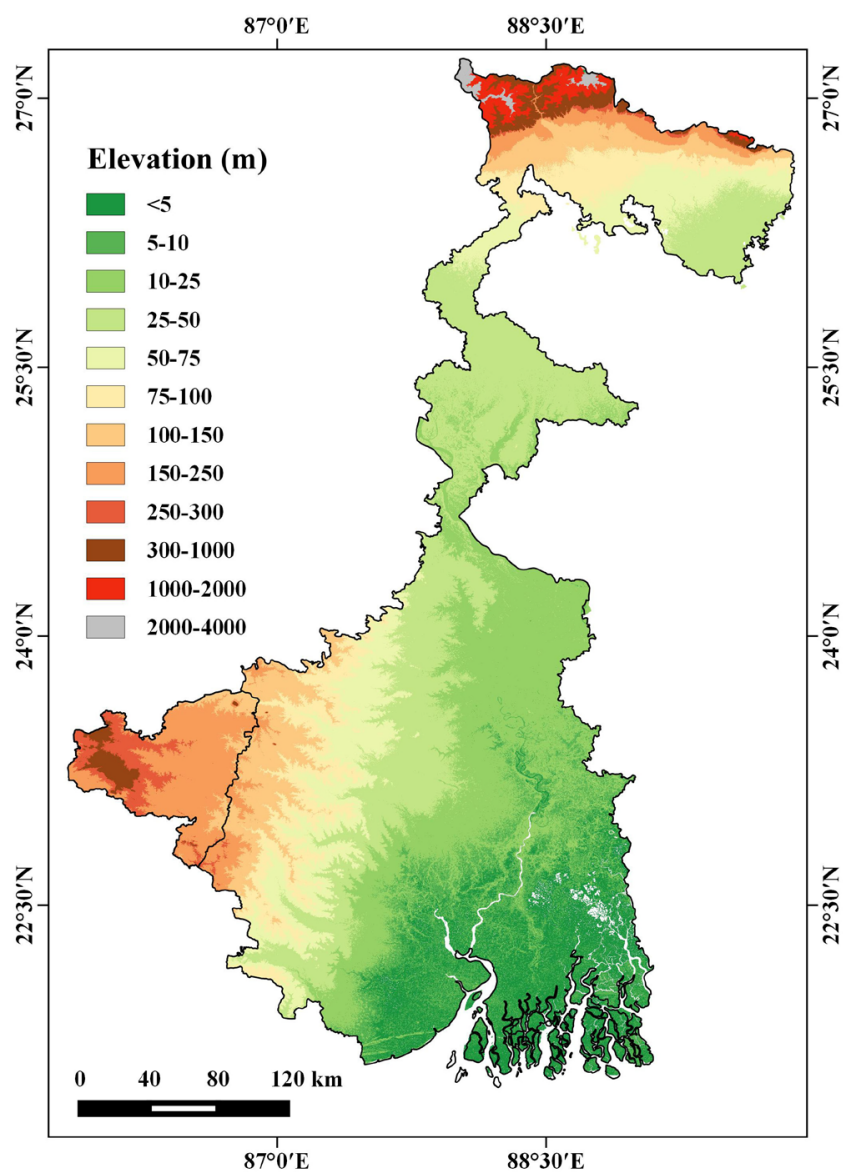

(b) 


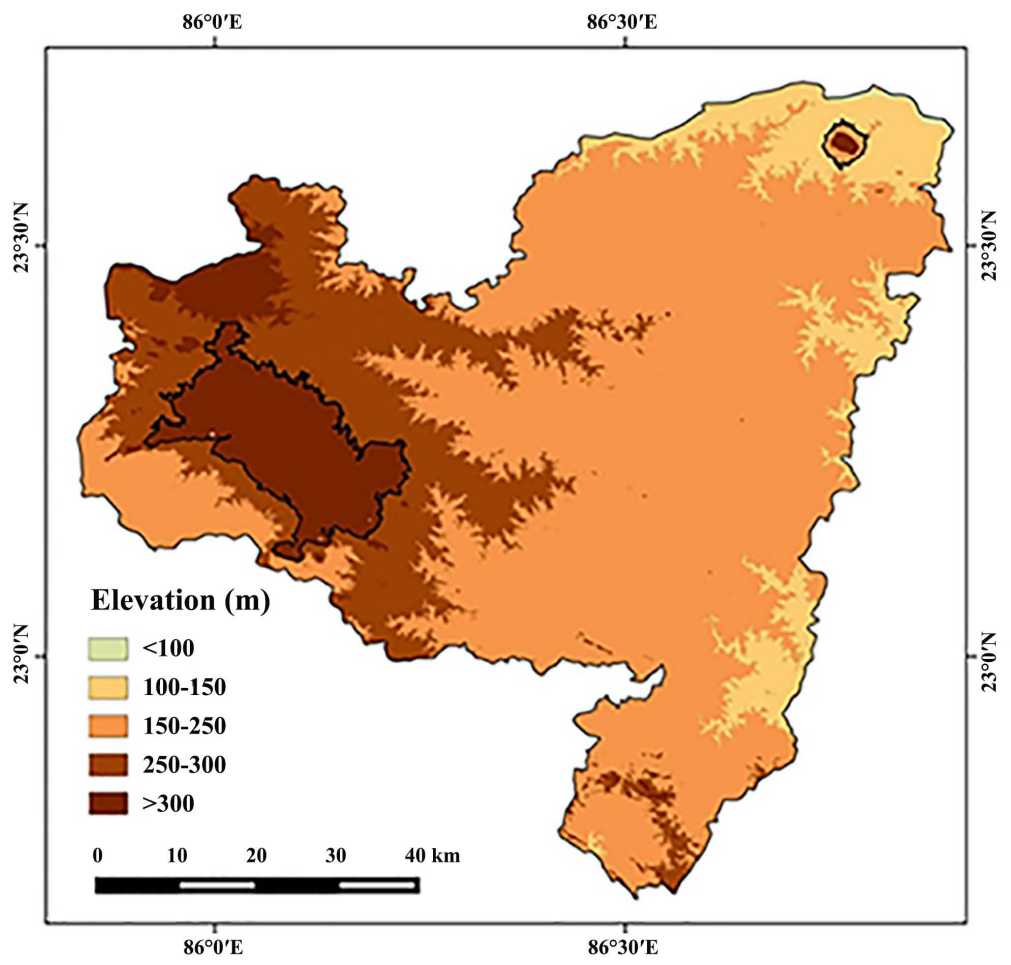

(c)

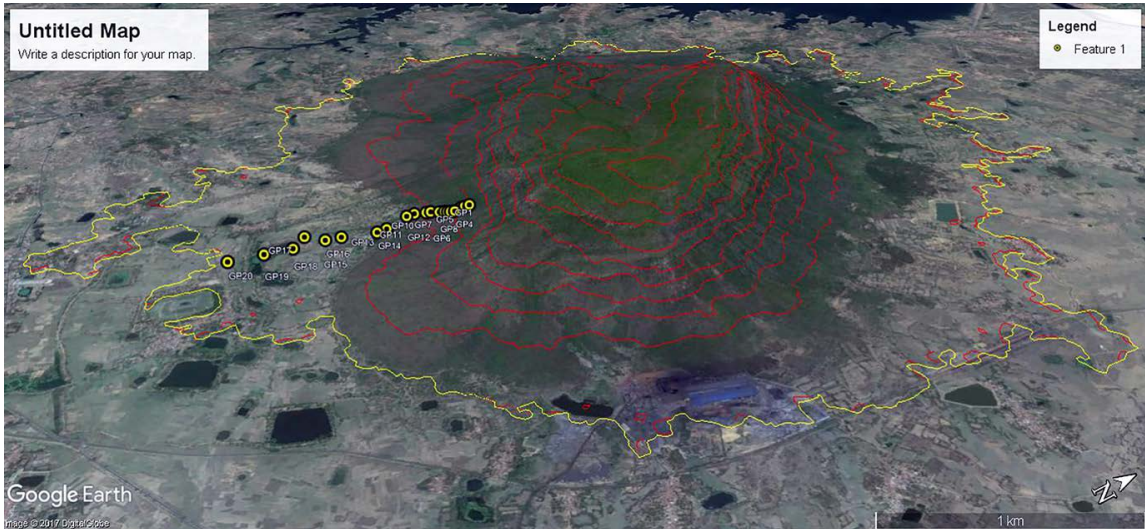

(d)

Figure 1. Map of India (a), Map of West Bengal (b), DEM of Puruliya district (c), Google photo of the Garpanchkot hill (d).

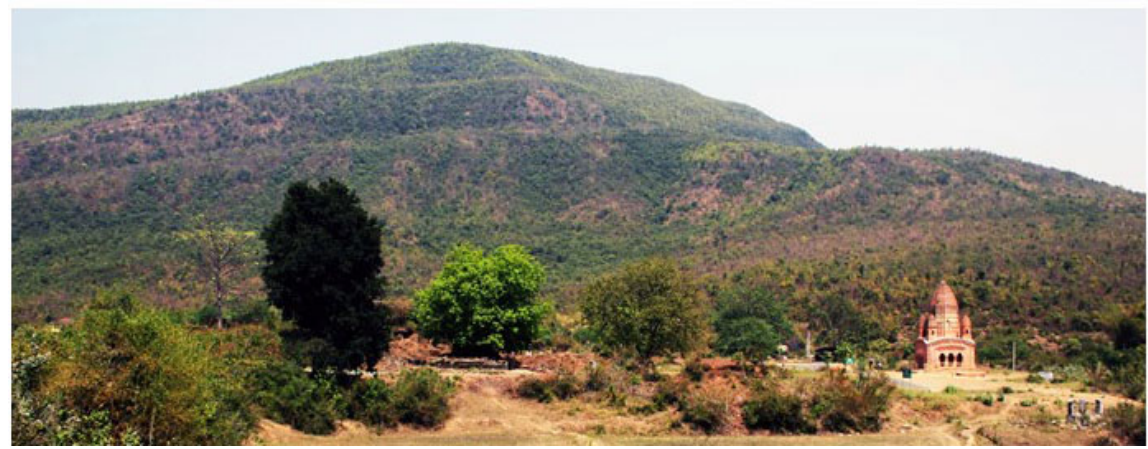

Plate 1. Garpanchkot hill. 
of research), 2) during field (collection of sample), and 3) post-field work activity (laboratory analysis, data evaluation and preparation of report). Laboratory analysis of sample has been done to find out pedological character. Geomorphological parameter (elevation, slope) has been analyzed by the application of geoinformatic techniques (Table 1). Statistical techniques have been used for establishment of soil geomorphological character. SRTM and ALOS data (Table 1) are analyzed by remote sensing software to find out the geomorphological character of the area. There are twenty soil samples have been taken (Figure 2(d)) from top of the hill to foothill pediment area with change of elevation and slope for laboratory analysis. Samples have been collected by random sampling method according to change of elevation measured by altimeter and global positioning system (GPS) receiver. Slope map has been prepared from remotely sensed elevation data. Sample points are identified by GPS receiver. Laboratory analysis of samples start with preparation of sample through sieving by mechanical shaker using $2 \mathrm{~mm}$ sieve and textural analysis of soil by hydrometer and Robinson's pipette method. Determination of soil structure has been done according to textural classification of Ontario center for soil resource evaluation. Soil permeability code has been determined based on textural classification after Ontario center for soil resource evaluation 1993. Percent of hygroscopic moisture has been measured by heating the air samples for three hours at a temperature of $105^{\circ} \mathrm{C}$ and calculating the percentage of moisture by noting the difference of weight. Percentage of soil organic matter was determined after Walkly and Black's wet combustion method, 1934. Global digital soil pH meter and digital conductivity meter have been used for determination range of soil $\mathrm{pH}$ and salinity. Soil analysis kit has been used for determination of status of NPK. Soil textural calculator of natural resource conservation services has been followed by soil textural plotting (Ternary diagram). This involves analysis of geomorphological and pedological data through regression and principal component analysis (PCA). Data presentation was done by different cartographic techniques.

Table 1. Details of satellite data, date of acquisition and resolution.

\begin{tabular}{cccc}
\hline Satellite and sensor & Date of acquisition & Path/Row & Band used spatial resolution \\
\hline Landsat 5 TM & $11 / 06 / 2011$ & $140 / 44$ & \\
& $11 / 06 / 2011$ & $140 / 43$ & $30 \mathrm{~m}$ \\
$02 / 04 / 2010$ & $139 / 44$ & \\
& $04 / 04 / 2014$ & $140 / 44$ & $30 \mathrm{~m}$ \\
Landsat 8 "OLI_TIRS" & $29 / 04 / 2014$ & $139 / 44$ & \\
& $22 / 01 / 2017$ & $140 / 44$ & $30 \mathrm{~m}$ \\
SRTM & $31 / 01 / 2017$ & $139 / 44$ & 1 Arc second \\
ALOS & $23 / 05 / 2010$ & & \\
\hline
\end{tabular}

Table has been prepared by the author. 


\section{Result and Discussion}

\subsection{General Geology and Geomorphology}

This area is an eastern extending part of Chota Nagpur plateau (Mahapatra, 2008; Bandyopadhyay et al., 2014). It has nearly about four to five thousands millions years' geological succession history (Bhattacharya et al., 1985). It is suspected that geological formation of this area has gone through Aeolian and glacial activity (Kumar, 1979). This area is composed of extensive variety of Archaean rocks (Mahapatra, 2008). The Gondwana composition is another important geological formation of this area (O'Malley, 1999). Formation of peninsular shield has been evidenced during Archean age, with granite and gneiss rock composition (GSI, 1999). This is the oldest age of rock formation of this area. Gondwana basin was formed by oceanic sediments (laterite) and Woodley materials (techno-fossils) during upper Carboniferous-Triassic periods. The hills and peneplane of this area are formed on the basement of peninsula shield on which Gondwana deposition took place. Archean formation mainly dominated by granitic (grey bedded biotite, granite, gneiss etc.), sedimentary and schistose rocks (phyllite, quartzite, schist etc.) (Dasgupta, 2015). Rock composed of glacial materials, fluviatile sandstone and shales formed during Gondwana system (Kumar, 1979; Bhattacharya et al., 1985). Laterite formation of this area is also product of the Gondwana age (Bhattacharya et al., 1985). This area is associated with undulating upland of residual hills, bed rock outcrops braided channel with occasional structurally controlled straight reaches and tributaries are mostly ephemeral (Bandyopadhyay et al., 2014). Garpanchkot hill is situated at the Ranchi plateau extended part of Chota Nagpur plateau.

Physiographic Expression can signify the presence of geomorphic processes, which are operating here throughout the year (Thornbury, 1954; Thomas, 1969). Some evidences can be cited for geomorphic process, which are evident in this area. This area is getting influenced by several topographic expressions. Significant break of slope is present from west to east. The area has a gentle undulating topography with occasional hillocks and elevation range between 650 meters to 50 meters from the mean sea level. This is the significant evidence of active to mature peneplanation process over this area. The Garpanchkot hill is composed of the Gondwana sedimentary rock (Kumar, 1979; Bhattacharya et al., 1985). This formation further continuous east ward direction into Bankura district and uplifted again as Biharinath hill. Panchet reservoir is situated at the north east foot hill of the Garpanchkot hill. Maximum elevated area of the hill is associated with peak elevation (Figure 2(a), Figure 2(e)). From the peak area elevation decreases gently towards the west and south-west (Figure 2(e)), but opposite of the peak and in the right side (north east to north west) of the peak steep escarpment with variant slope is formed due to suddenly decrease of elevation. Foot hill area is almost flat $(<150 \mathrm{~m})$ (Figure 2(a)). Top of the hill area remains flat and it continuous from north-east up to south-west. Maximum rugged topography is formed in the northern side of the hill. Ruggedness of the top of the 


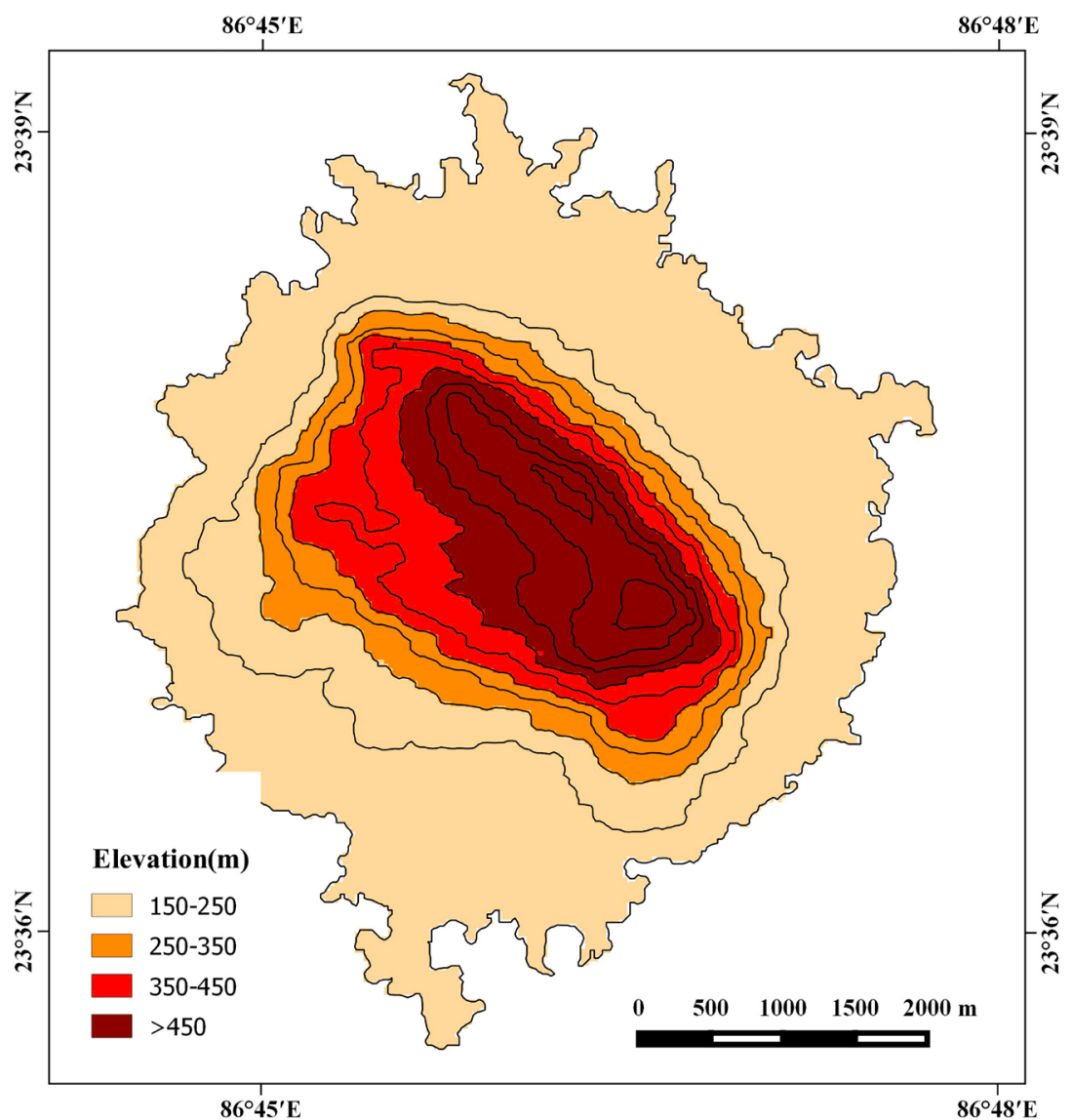

(a)

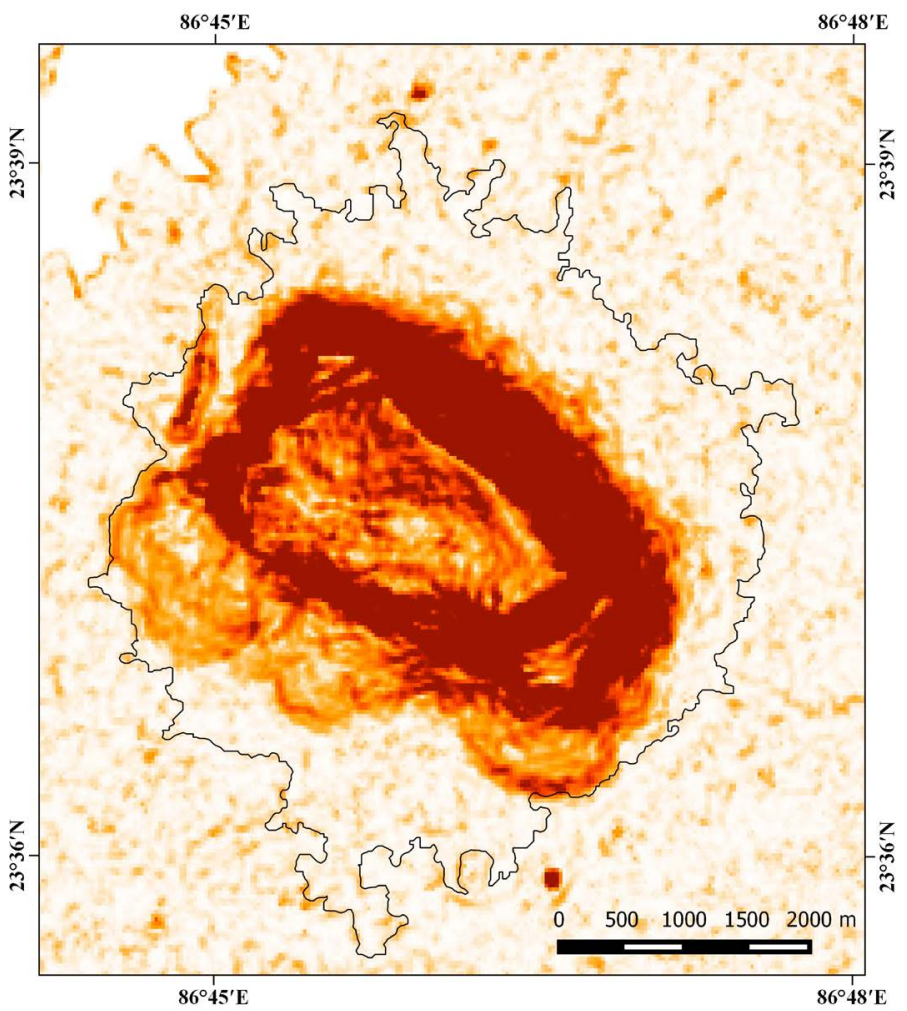

Ruggedness index

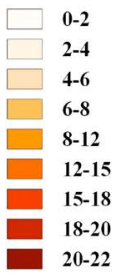

(b) 


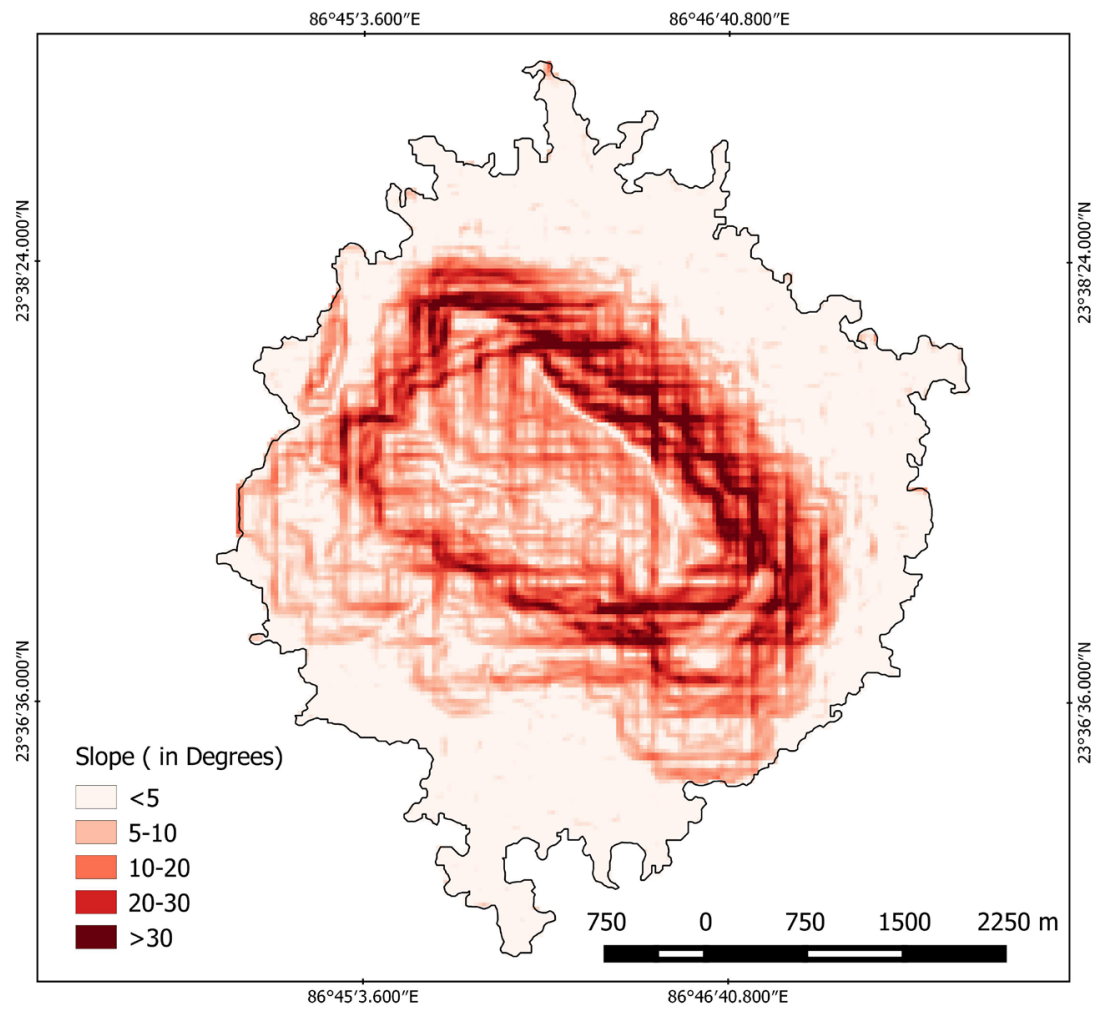

(c)

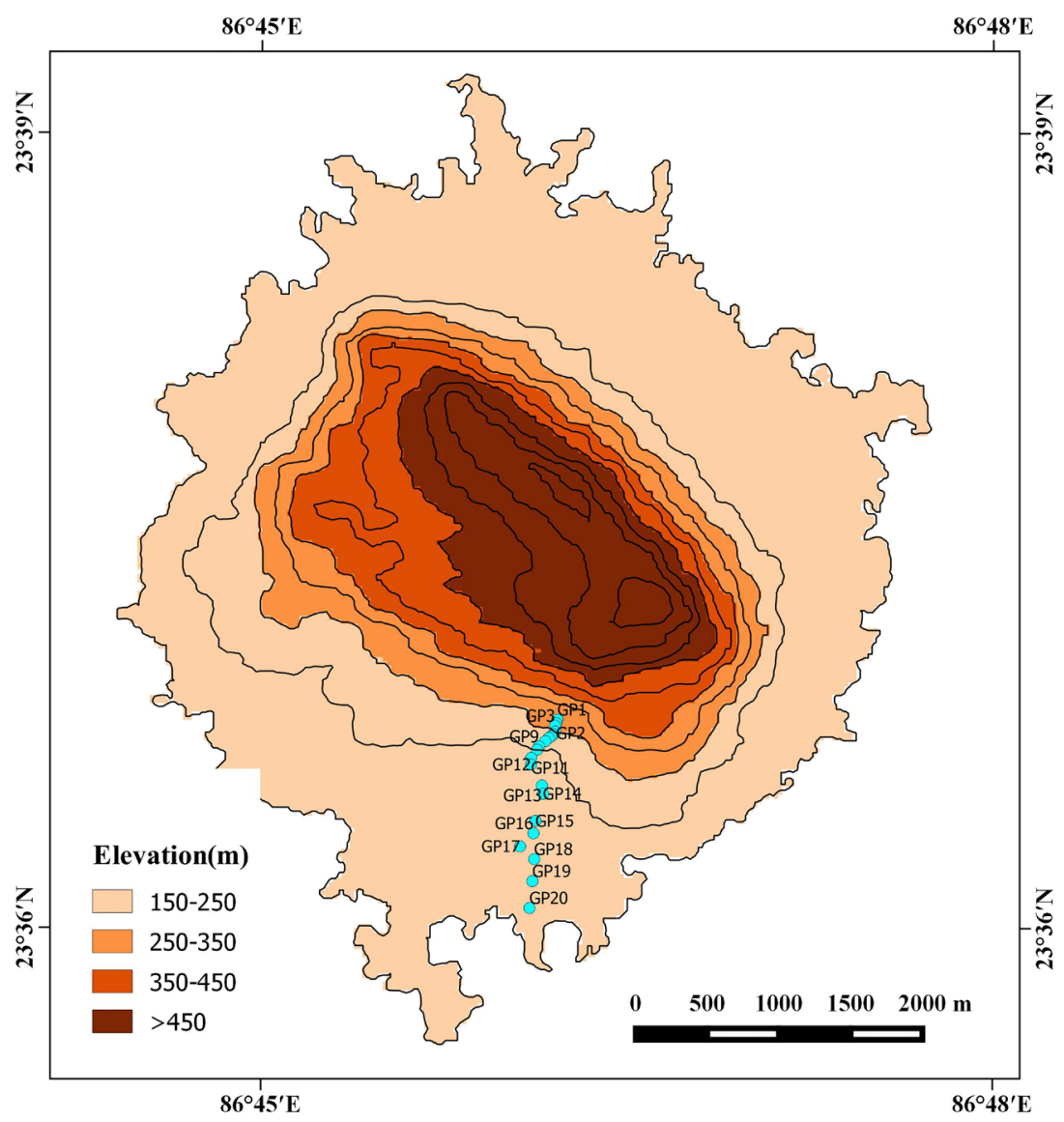

(d) 


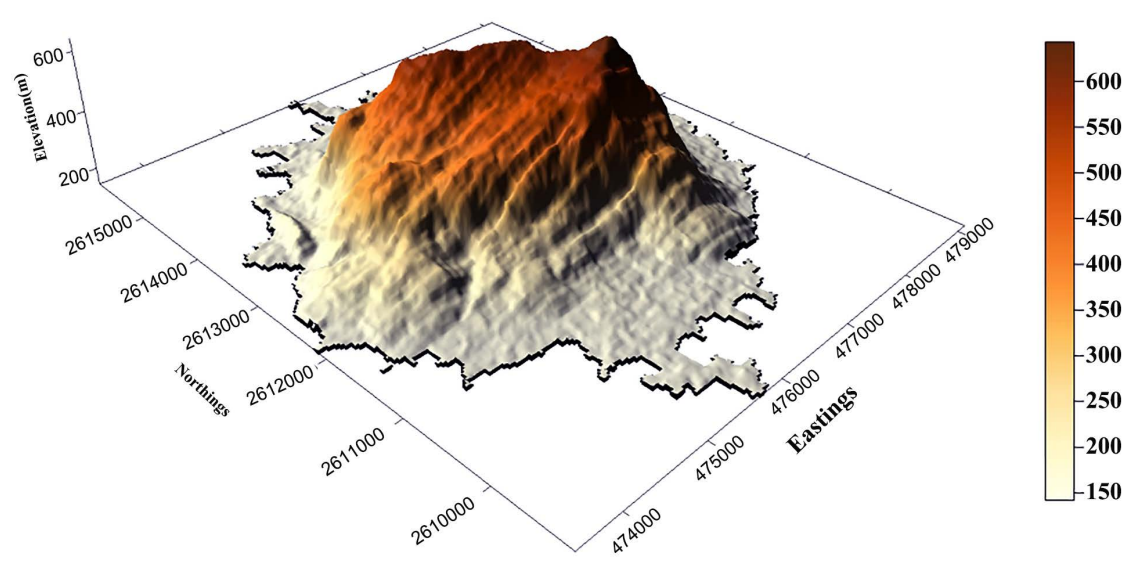

(e)

Figure 2. Elevation map (DEM) of Garpanchkot hill (a), Ruggedness index map of Garpanchkot hill (b), Slope map of Garpanchkot hill (c), Sampling point of Garpanchkot hill (d), 3D map of Garpanchkot hill (e).

hill is almost as same as foothill. Southern side of the hill is associated with less rugged topography (Figure 2(b)). Ruggedness of the foothill area is very less and it varies between $0-4$ in ruggedness index value. Escarpment area of the hill is very rugged in character. Foothill pediment area of the Garpanchkot hill is characterized by low ground slope (Figure $2(\mathrm{c})$ ), which ranges between $2^{\circ}-7^{\circ}$. Slope varies from $16^{\circ}-41^{\circ}$ in the escarpment area of the hill. Opposite side of the escarpment is characterized by relatively gentle slope, ranges between $2^{\circ}$ $16^{\circ}$. Foothill area is extended up to north and south to the maximum limit.

\subsection{Soil Character}

Soil of this hill area is two in type as residual soil and transported soil (Bhattacharya et al., 1985). Hill area is fully covered by residual soil. It is found at same location of their formation. It is formed by deep weathering, decomposition and disintegration of bed rock. Depth of the residual soil varies between 5 to 20 meters depends on amount of slope (Das et al., 2010). Degree of rock decomposition exceeds the role of transportation of weathered facilitated by dense forest and vegetation cover in this area. Residual soil produced by the destructive weathering process and constructive soil forming process. Weathering takes place in the high elevated residual hill but the plains associated foothill area remain erosion prone. Depth of the soil in the foothill pediment area relatively is thick. Transported soil is present in the foothill pediment area (Das et al., 2010; Ghosh, 2013). An insufficient leaching action takes place. The rate of chemical weathering decreases from surface to the sub surface. So depth of residual soil remains poor with less thickness. Transported soil of foothill pediment area has been carried out from higher elevated area by the tributaries. Gneissic soil, Gondwana soil, transition soil are three types of soil of this region (Bhattacharya et al., 1985; Das et al., 2010; Ghosh, 2013).

Percentage composition of sand, silt and clay plays an important role for de- 
termined basic nomenclature of texture class (Lahiri, 1964; Brady, 1999). The area is fully dominated by sandy loam soil; other important soil textural type is loamy sand (Figure 3). This type of soil is usually made of sand along with lower amounts of silt and clay. It is very suitable for agriculture. This type of soil has good drainage condition. This type of soil must have more than $65 \%$ of sand particle by volume in a sample. It also allows conditions for good vegetation growth. Sandy loam soil type has some structure and relatively good quality in fertility. More than $75 \%$ soil sample of the study area is bearing the characteristics of loamy sand and sandy loam, other predominant soil texture is sandy clay loam and occasionally loam. Clay loam and silt clay are two less important soil types of this area. In the year of 1993 Ontario Centre for Soil Resource Evaluation had made a soil texture code based on soil textural classification (Figure 4(a)). This system has four structural codes; each code contains different soil type according to their texture. The area falls under code 2 . Structure code 2 is associated with sandy loam, loam and silty sand soil type. Another important code is 1 . In this discussion structure code 1 is loamy sand and sand in soil type. There are $65 \%$ of samples are under structure code 2 (USDA: sandy loam; Ontario: sandy loam, loam, silty sand). Ontario Center for Soil Resource Evaluation has designed permeability code based on soil type (Figure 4(b)). Here author has put five statuses along with Ontario permeability code that is also associated with USDA specified soil type. In this present study, more than 50 percent samples of all four study areas belong to permeability code 2 , that is medium permeable in character.

According to structure code (Figure 4(a)) and permeability code (Figure 4(b))

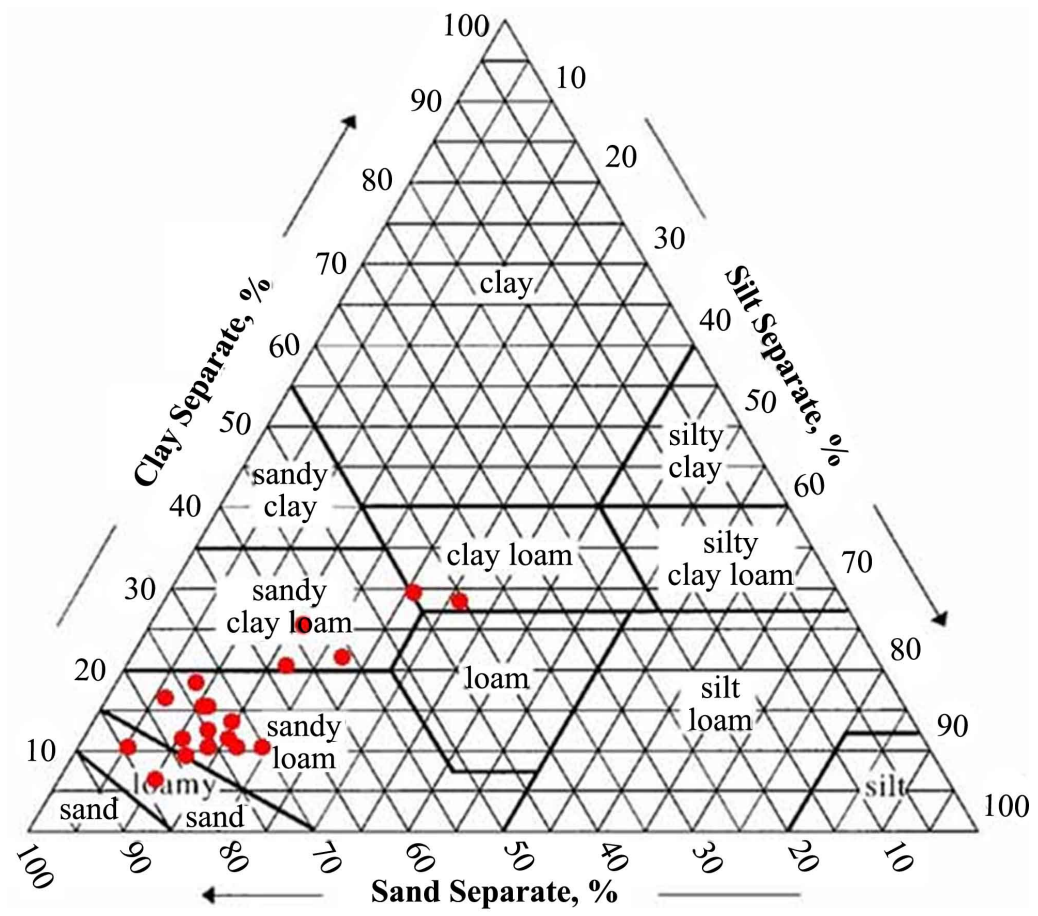

Figure 3. Soil textural diagram of Garpanchkot hill. 


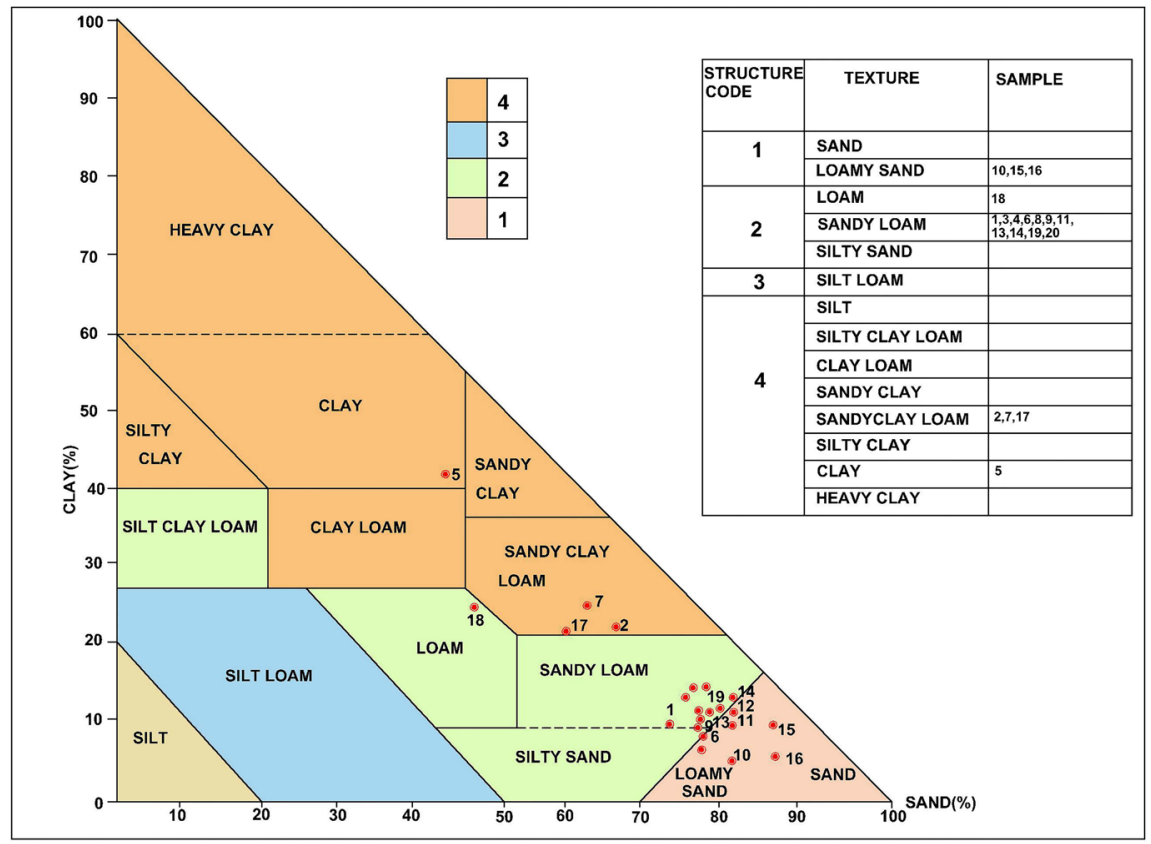

(a)

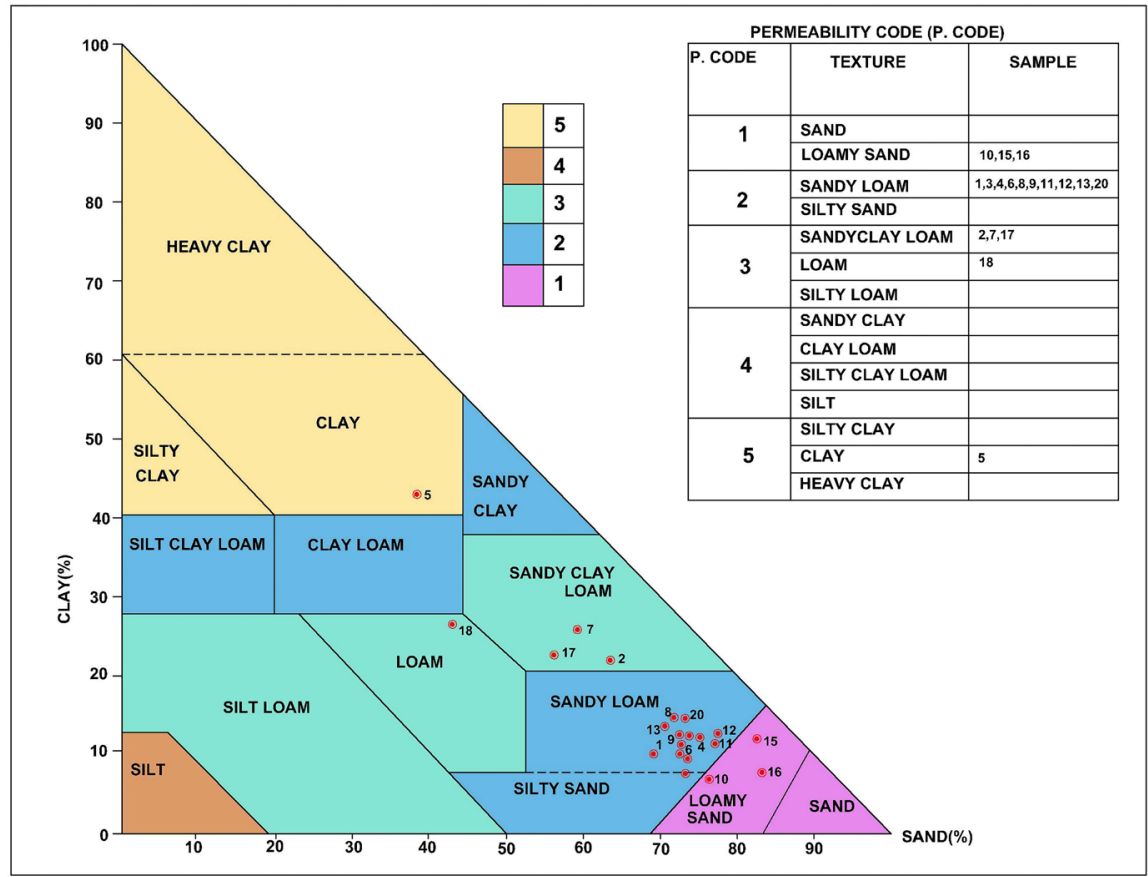

(b)

Figure 4. Soil texture code based on soil textural classification of Garpanchkot hill (a), Soil permeability code based on soil textural classification (b).

sandy loam is principal soil texture of this area. Percentage of hygroscopic moisture in to surface soil ranges between .5 and 1.5 (Figure 5(a)). Percentage of organic matter ranges between .5 and 2 (Figure 5(b)). Percentage of organic matter remains high in the escarpment grassland and high elevated forest cover. Percentage of hygroscopic moisture is also remaining high in the foothill pediment 

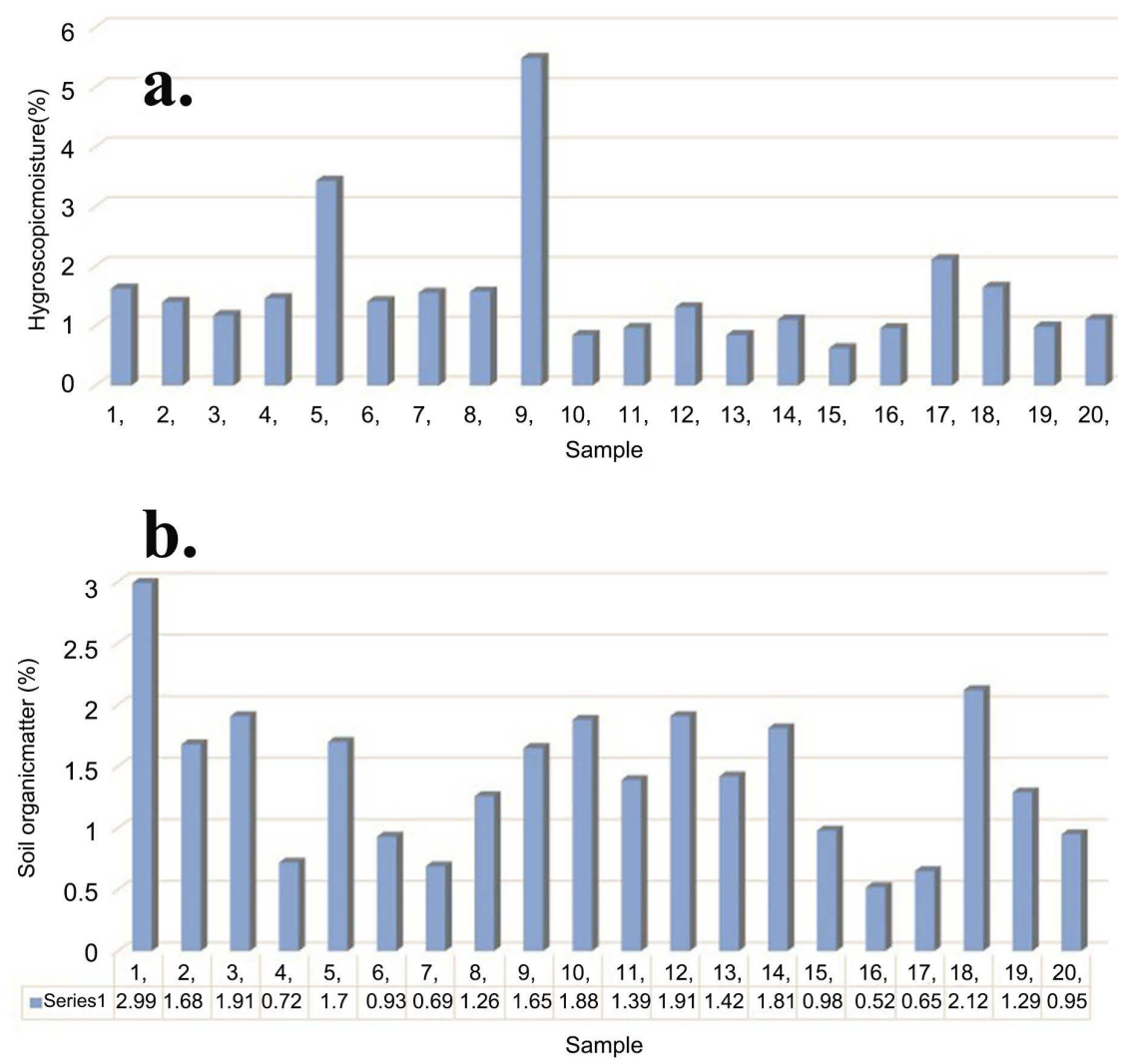

c.

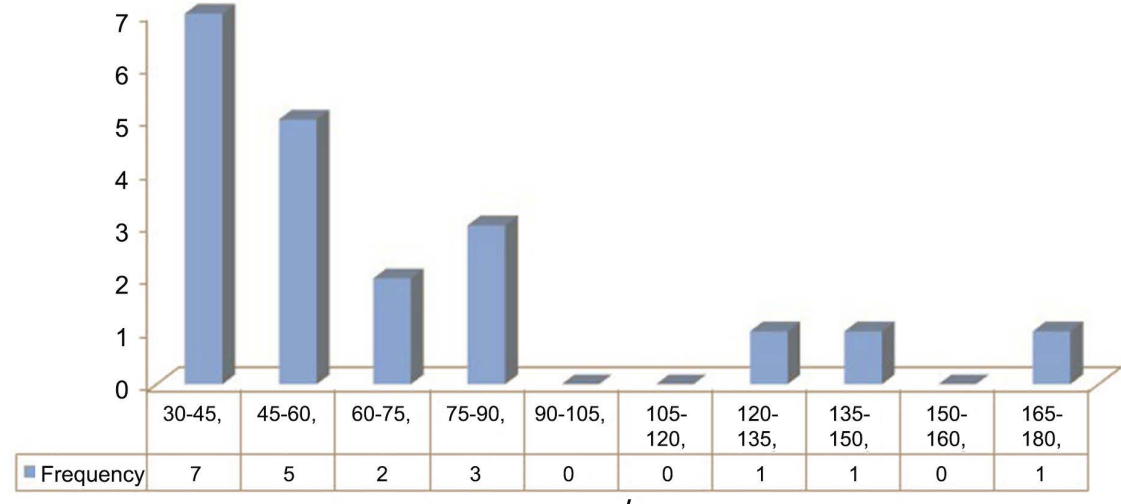

$\mathrm{us} / \mathrm{cm}$

Figure 5. Percentage of Hygroscopic moisture in Garpanchkot hill area (a), Percentage of soil organic matter in Garpanchkot hill area (b), Soil salinity of Garpanchkot hill area (c).

area. Soil salinity ranges between $30-90 \mu \mathrm{s} / \mathrm{cm}$ but soil salinity of maximum area of this hill ranges between $30-60 \mu \mathrm{s} / \mathrm{cm}$ (Figure 5(c)). So it can be said that status of soil salinity of this area is low to normal in character. Soil $\mathrm{pH}$ is neutral in character (Table 2). Status of nitrate nitrogen is remaining high. Ammoniacal nitrogen and phosphorus ranges between medium and low. Status of potassium is low in the surface soil in the area.

\subsection{Soil Geomorphology}

Analysis of soil-geomorphic attributes is an essential part of soil-geomorphological 
Table 2. Range of $\mathrm{pH}$ of samples of the study areas.

\begin{tabular}{ccc}
\hline Denomination & $\mathrm{pH}$ range & Occurrence of sample (\%) \\
\hline Extremely acid & $3.5-4.4$ & 10 \\
Very strongly acid & $4.5-5.0$ & - \\
Strongly acid & $5.1-5.5$ & - \\
Moderately acid & $5.6-6.0$ & - \\
Slightly acid & $6.1-6.5$ & - \\
Neutral & $6.6-7.3$ & 10 \\
Slightly alkaline & $7.4-7.8$ & 75 \\
Moderately alkaline & $7.9-8.4$ & 5 \\
Strongly alkaline & $8.5-9.0$ & - \\
Very strongly alkaline & $>9.0$ & - \\
\hline
\end{tabular}

Table has been prepared by the author.

research. Character of soil catena differs with the change of elevation and slope character of the area. Parent material is an active soil-geomorphic attribute as well as passive soil forming factor. Soil of the study area can be considered as Ectodynamorphic soil. Soil texture of Garpanchkot hill area is extremely influenced by the siliceous types of parent material and produced sand dominated soil texture. Rainfall and temperature are important dominant factors of soil formation. That also acts as soil geomorphological attribute. Less slopped foothill area is associated with thick alluvial deposition with rich in minerals. Soil catena of the study area is developed from uniform parent material. Here topography has influence on surface soil. Slope influence drainage condition as well as moisture balance in the soil profile. Soil down to the hillslope is rarely uniform in character. Soil eroded from the top of the hill area tends to accumulate (transported soil) near to the foothill pediment area. Here is significant relationship between elevation and soil character as well as slope and soil character.

Topography plays an important role for spatial distribution and characteristics of pedological attribute. Here percentage of sand is decreasing with increase of elevation. Percentage of silt and clay are increasing with increase of elevation. There is positive relationship between elevation versus HM fallowed by elevation versus SOM. Positive relation has been found between elevation and $\mathrm{pH} . \mathrm{pH}$ increases with increase of elevation. Negative relation is found between elevation and soil salinity. Salinity decreases with increase of elevation. Soil of top of the hill area is associated with slightly alkaline denomination in $\mathrm{pH}$ range (Figure 6).

Negative relation is found in slope versus sand, silt and salinity. Steep sloping area is unable to hold sand and silt due to gravitational pool towards the foothill area. After disintegration of the parent rock, sand remains dry and loose. Sand is unable to hold moisture. That has been carried out by the surface runoff with first shower of monsoon. Silt has the same tendency. Another negative relationship 

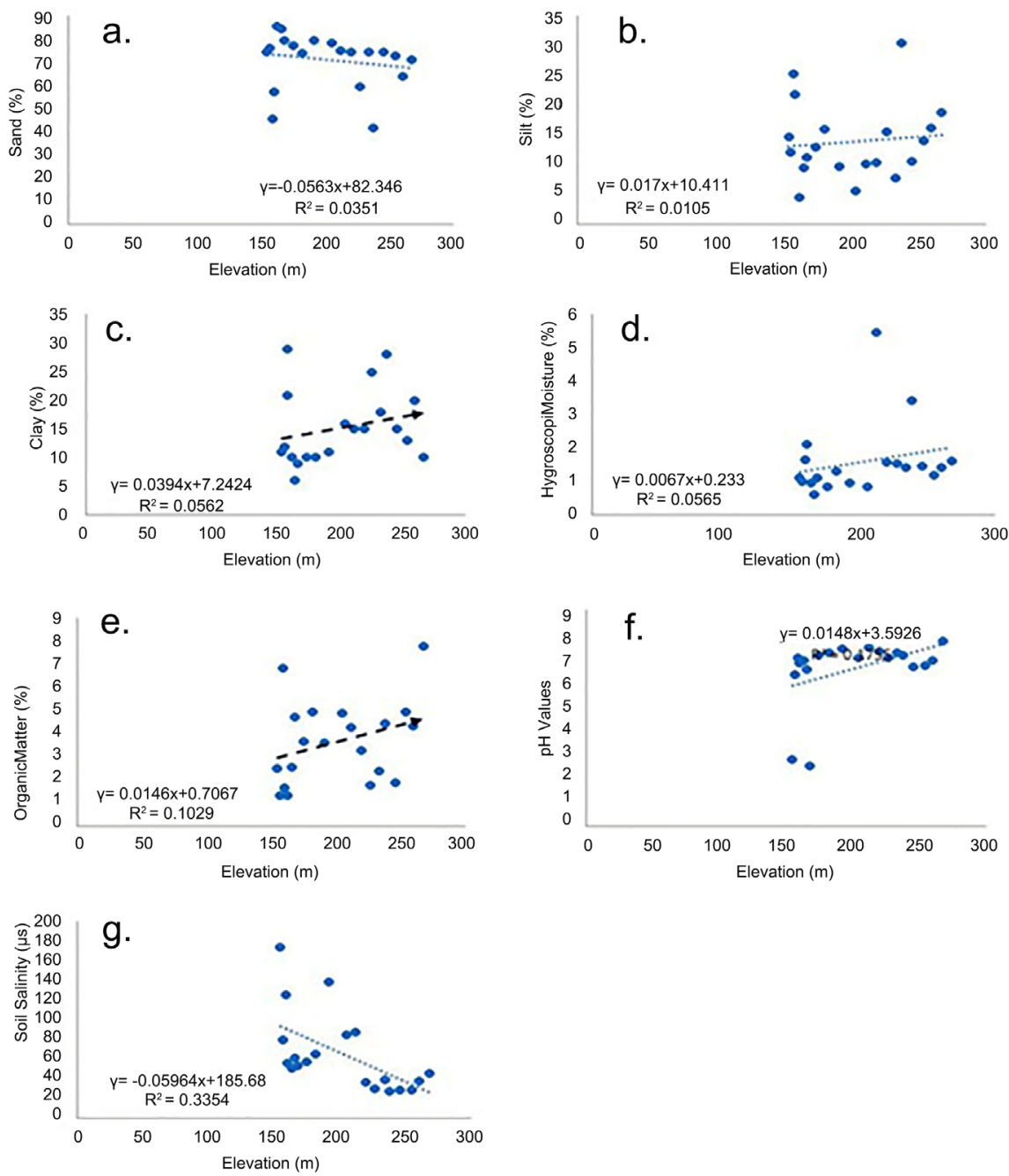

Figure 6. Relationship between elevation and sand (a), silt (b), clay (c), hygroscopic moisture (d), organic matter (e), $\mathrm{pH}$ (f), salinity (g).

is found between slope and soil salinity. Soil salinity is decreases with increase of slope. Slope becomes positive factor for percent of clay, HM, SOM and $\mathrm{Ph}$ (Figure 7). Sometime grass dominated steep sloping area can hold clay mineral. That is extracting from the surface runoff by its root stem and leaf. Greater percent of HM is also hold by the grass associated escarpment area. Grassland and occasionally scattered vegetation dominated steep sloping area produce large percent of organic matter to the soil. Decomposition of this SOM can increase the activity of the soil.

Depending upon the following data principal component analysis (PCA) has been done among the basic parameter elevation, slope, sand, silt, clay, HM, SOM, salinity and alkalinity. In initial result of PCA analysis first Eigen values equals 3.44 and represents 38.24 percent of total variability. This also indicates percentage of the total variability of the data in one axis. The Eigen value of elevation (variable 1), slope (variable 2) and sand (variable 3 ) are corresponds to a high percentage $(38.24 \%, 24.55 \%, 11.53 \%)$ of the variance. Cumulative percentage 

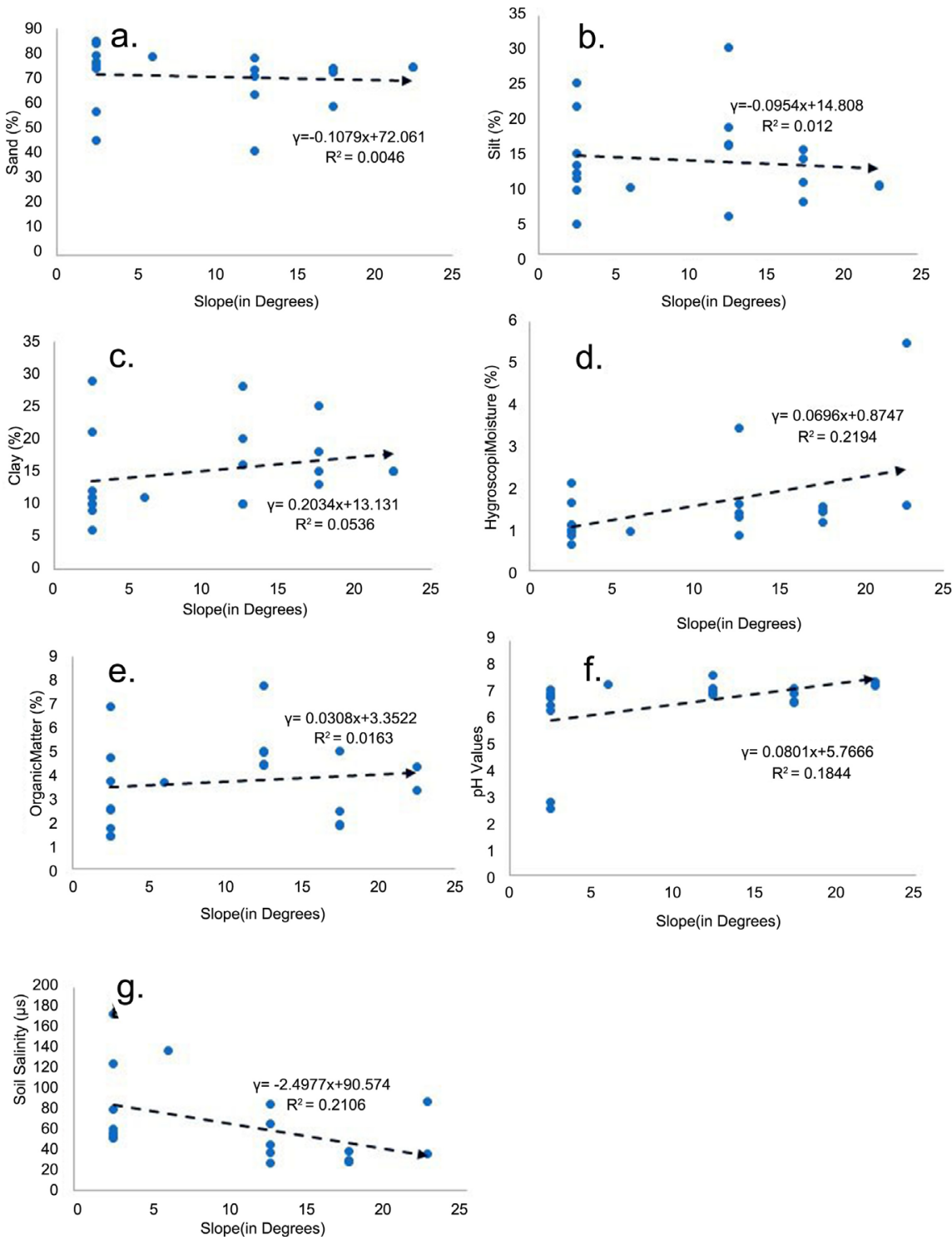

Figure 7. Relationship between slope and sand (a), silt (b), clay (c), hygroscopic moisture (d), organic matter (e), $\mathrm{pH}(\mathrm{f})$, salinity (g).

of variability of first four components (elevation, slope, sand and silt) is 84.32 (Table 3). Here first four components explain the 75 of variability. So the analysis is very well explained.

\subsection{Soil Geomorphology, Land Use and Land Cover}

Categories of land use and land cover of that area have been developed on the basis of soil geomorphological character. Dense forest is located on the high elevated less slopped areas. Moderate vegetation is located on the medium elevated and relatively greater slopped areas. Steep slopped and escarpment area are dominated by scattered vegetation and grass land. Agriculture is developed on the foothill pediment areas where elevation and slope is very less and thick layer of relatively fertile soil is present. Depth of the soil at escarpment area is less. 
Table 3. Summary of PCA analysis.

\begin{tabular}{|c|c|c|c|c|c|c|}
\hline \multirow[b]{2}{*}{ Study area } & \multicolumn{5}{|c|}{ Summary of PCA analysis } & \multirow[b]{2}{*}{ Remarks } \\
\hline & Component & $\begin{array}{l}\text { Percentage } \\
\text { of variability }\end{array}$ & $\begin{array}{l}\text { Cumulative } \\
\text { ntage of varia }\end{array}$ & $\begin{array}{c}\text { Total variability } \\
(>75 \% \text { explanation })\end{array}$ & $\begin{array}{l}\text { Total number of component } \\
\text { up to ( } 75 \% \text { explanation) }\end{array}$ & \\
\hline \multirow{4}{*}{ Garpanchkot hill } & Elevation & 38.24 & 38.24 & \multirow{4}{*}{84.32} & \multirow{4}{*}{4} & \multirow{4}{*}{$\begin{array}{l}\text { Very well } \\
\text { explained }\end{array}$} \\
\hline & Slope & 24.55 & 62.79 & & & \\
\hline & Sand & 11.53 & 74.33 & & & \\
\hline & Silt & 9.99 & 84.32 & & & \\
\hline
\end{tabular}

Table has been prepared by the author.

High elevated forest areas are less slopped where soil thickness is greater than escarpment area. There are six land use (LU) and land cover (LC) categories have developed in the present study. The land cover categories are dense forest, moderately dense forest (moderate forest), forest and scattered vegetation. The land use categories are current fallow and agricultural land. In association with the land use and land cover classification three band rationing processes, i.e. normalize difference vegetation index (NDVI), normalize difference water index (NDWI) and land surface temperature (LST) (Figure 8(a)) are used for support of land use and land cover (LULC) (Figure 8(b)) classification. Forest area is associated with high NDVI values (Figure 9(a)). That denotes good health of vegetation. High NDWI value associated with high moisture contented area (Figure 9(b)) and less temperature respect to surrounded area. Bare soil ground is associated with less NDVI values which state about presence of less vegetation in this area (Figure 9(a), Table 4). Less NDWI values denote about the less available water content and high (Figure 9(b), Table 4) temperature. Significant relationships have been found among the LULC categories, geomorphology and soil character (Table 5, Figure 10) dense forest located at the elevation of $200 \mathrm{~m}$ and above (Plate 2). Where slope is ranges between $10^{\circ}$ and $15^{\circ}$. Forest area dominated by sandy loam soil texture, with .5 to 2.12 percent soil organic matter and .2 to .58 percent soil moisture. Range of $\mathrm{pH}$ is 6.40 to 7.66 . But land use activity is limited at the foothill area (elevation less than $200 \mathrm{~m}$ and slope less than $5^{\circ}$ ). Soil texture of foothill pediment area is clay loam and sandy clay loam. Clay has been accumulated in the foothill pediment area (Plate 3) from top of the hill area by overland flow. Foothill agriculture system is possible by monsoon rainfall.

Status of ammoniacal nitrogen is low in higher elevated area but it remains medium in foothill area (Table 6). Status of Nitrate nitrogen is high in higher elevated area as well as foothill area. Status of Phosphorus and Potassium in change of elevation remains low (Table 6 ). When slope is maximum $\left(>20^{\circ}\right)$ then status of ammoniacal nitrogen is low, but it remains medium in less sloped $\left(<15^{\circ}\right)$ area (Table 7). Status of Nitrate nitrogen is high in changes of slope (Steep slope escarpment to less sloped foothill area) (Table 7). Status of Potassium is low in changes of slope (Steep slope escarpment to less sloped foothill 


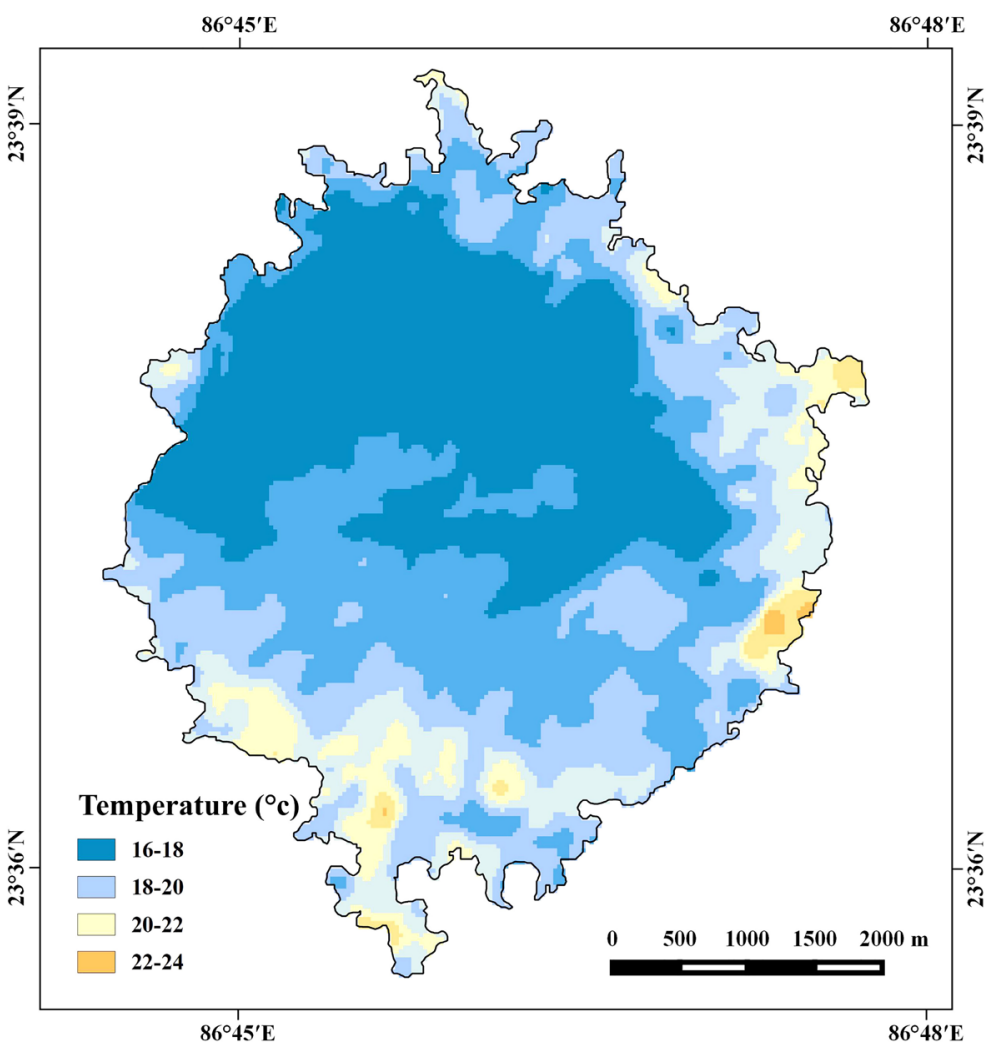

(a)

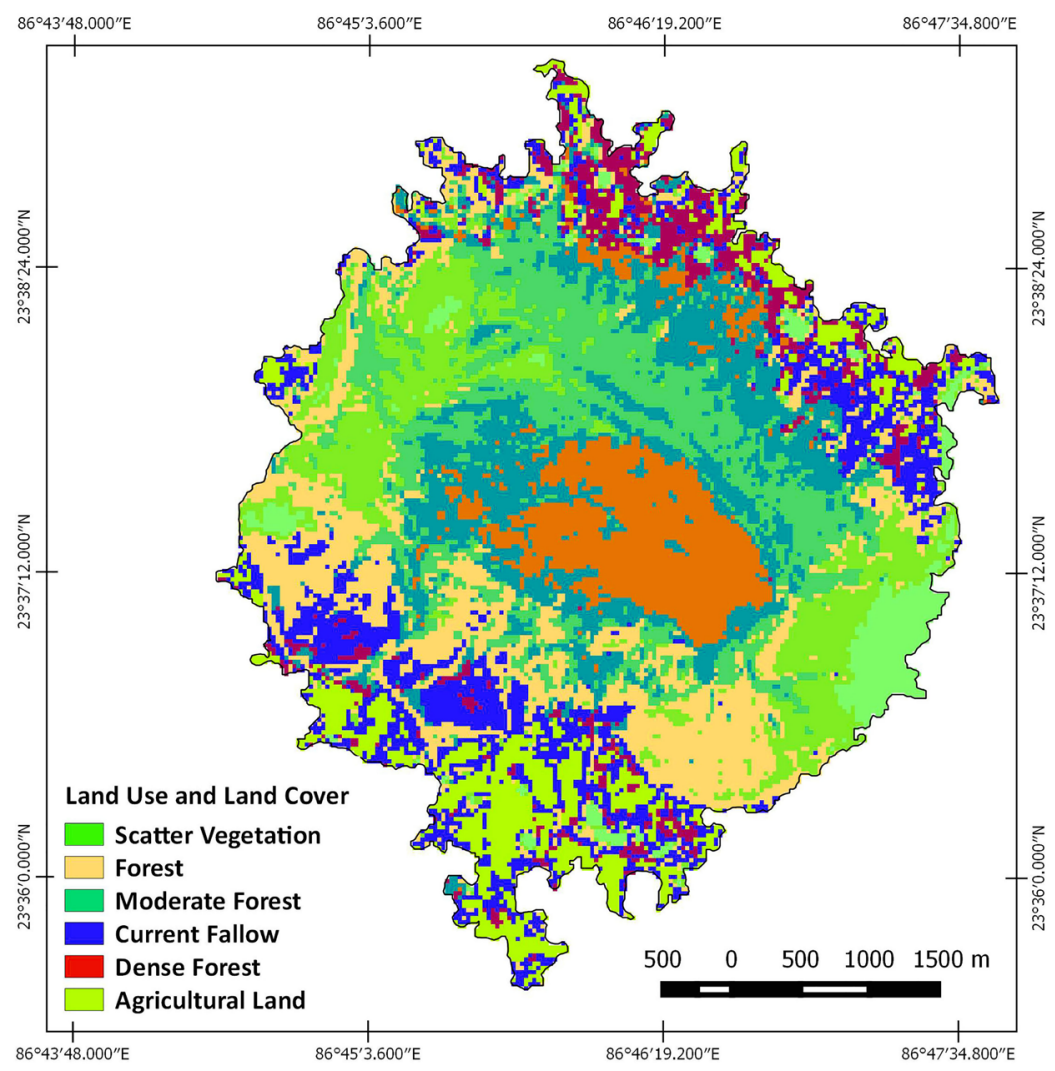

(b)

Figure 8. LST map of Garpanchkot hill (a), LULC map of Garpanchkot hill (b). 
Table 4. Comparison between LULC categories, NDVI, NDWI, LST.

\begin{tabular}{cccc}
\hline LULC categories & NDVI values & NDWI values & LST values \\
\hline Dense forest & $.38-.46$ & $>.15$ & $16^{\circ} \mathrm{C}-18^{\circ} \mathrm{C}$ \\
Moderate forest & $.33-.38$ & $.10-.15$ & $16^{\circ} \mathrm{C}-18^{\circ} \mathrm{C}$ \\
Forest & $.28-.33$ & $.10-.15$ & $18^{\circ} \mathrm{C}-20^{\circ} \mathrm{C}$ \\
Scattered vegetation & $.20-.28$ & $.05-.10$ & $18^{\circ} \mathrm{C}-20^{\circ} \mathrm{C}$ \\
Current fallow & $.06-.15$ & $.01-.05$ & $20^{\circ} \mathrm{C}-22^{\circ} \mathrm{C}$ \\
Agricultural land & $.15-.20$ & $.05-.10$ & $16^{\circ} \mathrm{C}-18^{\circ} \mathrm{C}$ \\
Water & $.00-.06$ & $>.15$ & $24^{\circ} \mathrm{C}-27^{\circ} \mathrm{C}$ \\
\hline
\end{tabular}

Table has been prepared by the author.

Table 5. Soil-geomorphology and Land use land cover of Garpanchkot Hill area.

\begin{tabular}{|c|c|c|c|c|c|c|c|}
\hline \multirow[b]{2}{*}{ Category } & \multicolumn{2}{|c|}{ Geomorphology } & \multicolumn{5}{|c|}{ Soil Character } \\
\hline & $\begin{array}{c}\text { Topography } \\
\text { (Elevation in meters) }\end{array}$ & $\begin{array}{c}\text { Morphology } \\
\text { (Slope in degrees) }\end{array}$ & Texture & $\begin{array}{l}\text { Soil organic } \\
\text { matter (\%) }\end{array}$ & $\begin{array}{l}\text { Hygroscopic } \\
\text { moisture (\%) }\end{array}$ & $\mathrm{pH}$ & $\begin{array}{l}\text { Salinity } \\
(\mu \mathrm{s} / \mathrm{cm})\end{array}$ \\
\hline Dense forest & $>250$ & $10-15$ & Sandy loam & $.69-2.99$ & $.84-1.31$ & $6.54-7.36$ & $53.5-138.6$ \\
\hline Moderate forest & $200-250$ & $\begin{array}{c}10-15 \\
5-10\end{array}$ & $\begin{array}{c}\text { Sandy loam, } \\
\text { Sandy clay loam }\end{array}$ & $1.39-1.81$ & $.84-.3 .42$ & $6.65-7.72$ & $27.6-87.6$ \\
\hline Scattered vegetation & $\begin{array}{l}200-250 \\
150-200\end{array}$ & $>15$ & Sandy loam & $1.39-1.8$ & $.84-3.42$ & $6.65-7.72$ & $27.6-87.6$ \\
\hline Fallow & $<200$ & $<5$ & $\begin{array}{l}\text { Sandy loam, } \\
\text { Loamy fine sand }\end{array}$ & $.52-2.12$ & $.62-2.11$ & $2.8-6.9$ & $51.2-174.1$ \\
\hline Current fallow & $<200$ & $<5$ & Sandy loam & $.52-2.12$ & $.62-2.11$ & $2.8-6.9$ & $51.2-174.1$ \\
\hline Agriculture & $<200$ & $<5$ & Sandy loam & $.52-2.12$ & $.62-2.11$ & $2.8-6.9$ & $51.2-174.1$ \\
\hline
\end{tabular}

Table has been prepared by the author.

Table 6. Relationship between elevation and status of NPK.

\begin{tabular}{ccccc}
\hline Elevation $(\mathrm{m})$ & AN & NN & P & K \\
\hline$>250$ & Low & High & Low & Low \\
$200-250$ & Medium & High & Low & Low \\
$175-200$ & Low & High & Low & Low \\
$<175$ & Medium & High & Medium & Low
\end{tabular}

${ }^{*}$ Ammoniacal Nitrogen (AN), Nitrate Nitrogen (NN), Phosphorus (P), Potassium (K). Table has been prepared by the author.

Table 7. Relationship between elevation and status of NPK.

\begin{tabular}{ccccc}
\hline Slope(Degree) & AN & NN & P & K \\
\hline$>20$ & Low & High & Low & Low \\
$\mathbf{1 5 - 2 0}$ & Medium & High & Low & Low \\
$10-15$ & Medium & High & Low & Low \\
$\mathbf{5}-\mathbf{1 0}$ & Medium & High & Low & Low \\
$<5$ & Medium & High & Medium & Low \\
\hline
\end{tabular}

*Ammoniacal Nitrogen (AN), Nitrate Nitrogen (NN), Phosphorus (P), Potassium (K). Table has been prepared by the author. 

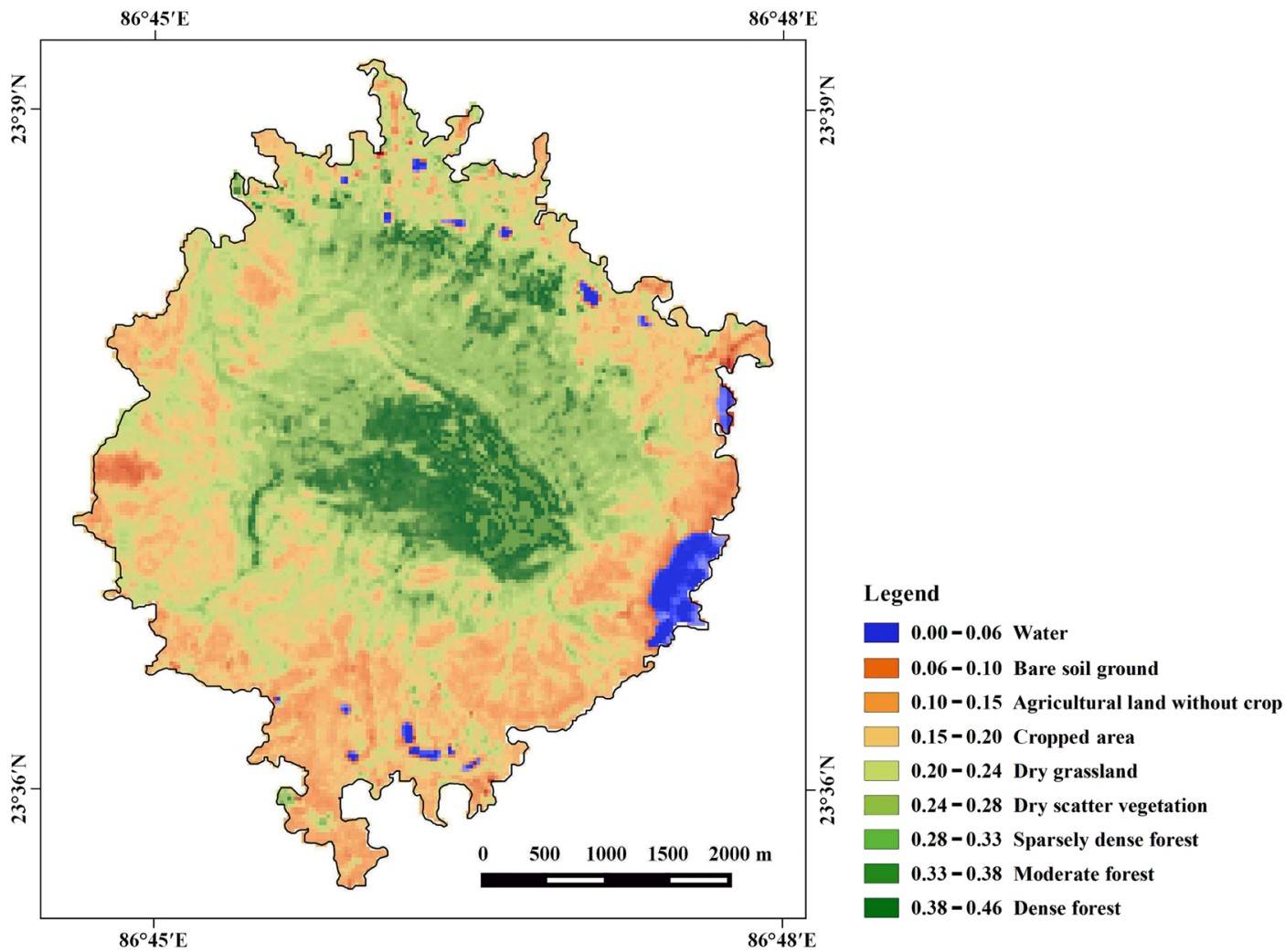

(a)

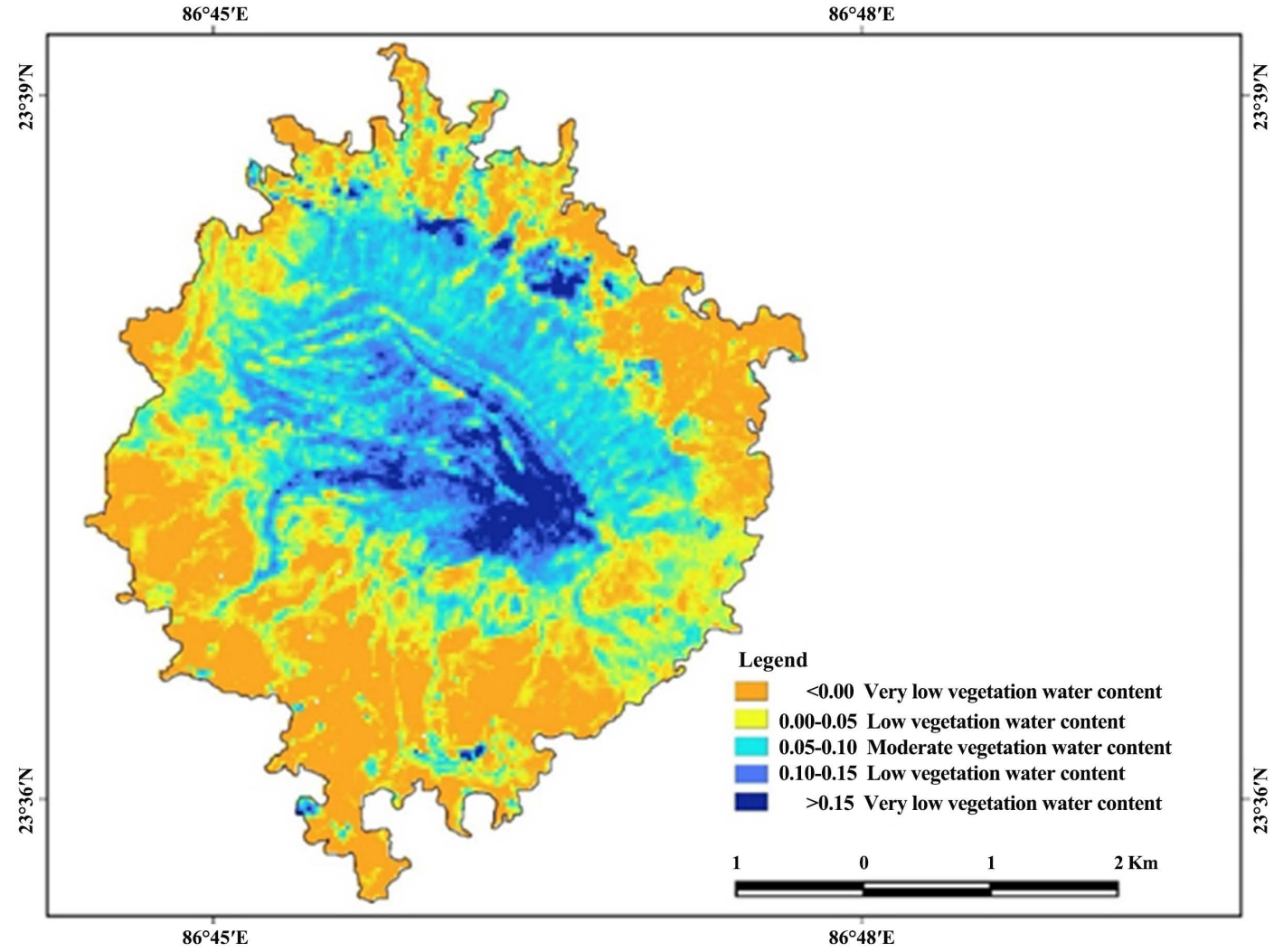

(b)

Figure 9. NDVI map of Garpanchkot hill (a), NDWI map of Garpanchkot hill (b). 


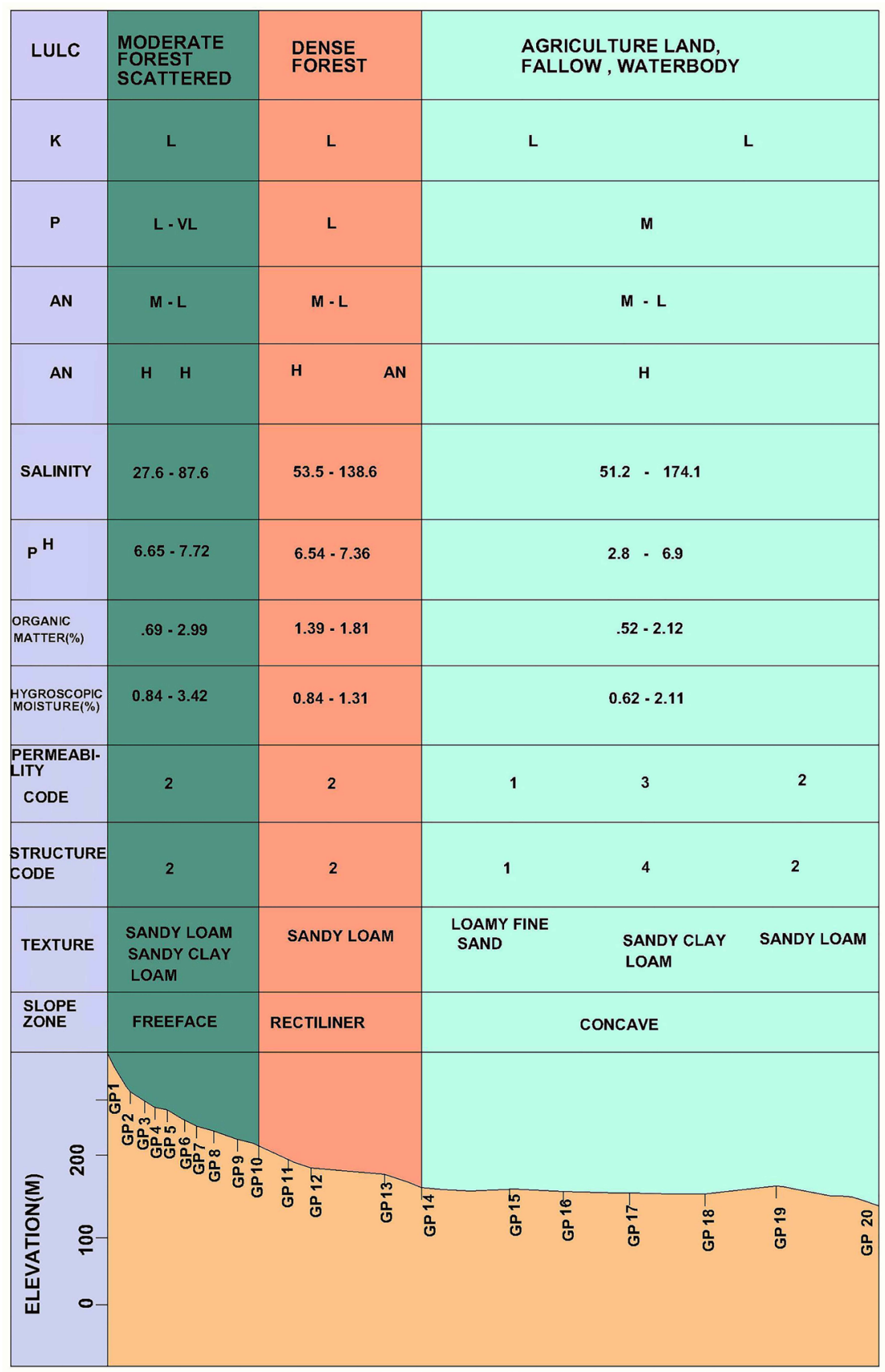

Figure 10. Transect chart showing relationship between pedogeomorphological character and land use land cover of Garpanchkot Hill.

area) (Table 7). Status of Phosphorus is medium in foothill area; rest of the area it remains low (Table 7). Sandy loam is dominant soil texture in higher elevated area, but foot hill area is associated with loamy fine sand and sandy clay loam soil texture (Table 8).

Foothill area is associated with agriculture practice. Farmers are producing rice, wheat, vegetables by ploughing and terrace method of cultivation. The method and techniques of cultivation of different crops in the foothill area of the hills vary from different extent (area to area). This area is also experiencing 



Plate 2. Dense forest (a), moderate forest (b), foothill scattered vegetation and fallow land.

Table 8. Relationship between elevation, slope and soil structure.

\begin{tabular}{cccc}
\hline Elevation $(\mathrm{m})$ & Soil structure & Slope (degrees) & Soil structure \\
\hline$>250$ & Sandy loam & $>\mathbf{2 0}$ & Sandy loam \\
$\mathbf{2 0 0 - 2 5 0}$ & Sandy loam & $\mathbf{1 5 - 2 0}$ & Sandy clay \\
$175-200$ & Sandy loam & $10-15$ & Sandy loam \\
& Loamy fine sand & $5-10$ & Sandy loam \\
$<175$ & Sandy clay loam & $<5$ & Loamy fine sand \\
& & &
\end{tabular}

Table has been prepared by the author. 

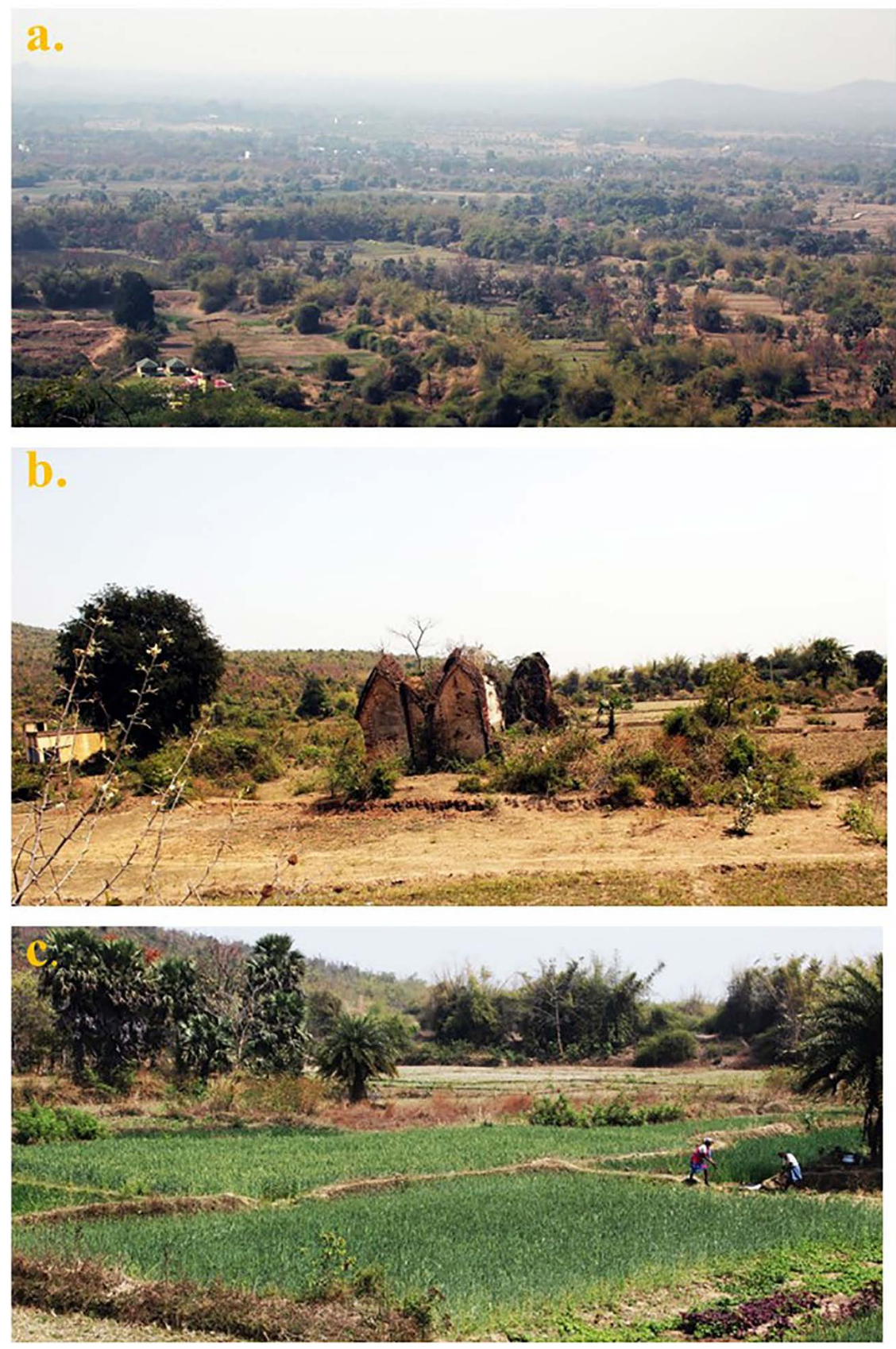

Plate 3. Foothill vegetation cover (a), bare ground (b), foothill agriculture land.

three types of rice crops (Aus, Amon and Boro) and Robi crop separately. Amon and Boro are most important crops due to lack of water. Boro is summer crop. It needs irrigation. In this regards irrigation can be done from natural and artificial water bodies. Water was stored during monsoon. It is an example of traditional rain water harvesting system. It is very common practice hare throughout the year. Boro seeds are sown during the month of November and December and they are transplanted during December to February. Boro crop is harvested during April and May. Amon is popular as winter paddy. It is sown in the month of July after the onset of monsoon. After the first rain in June due to south west mon- 
soon, farmers of the area start to prepare their field for cultivation. The paddy is sown in a particular part of the field for seedling. Transplantation is carried out during the month of July to August. This crop has grown up during monsoon season and harvested in the month of November and December. The season during November to January is known as Robi season. The paddy grown during this time is called Boro crop. It is cultivated in the low laying marshy land and edge of the water bodies of the foothill area.

\section{Findings}

Present landscape of this area has the influence of climatological and geological succession throughout the geological; past. Breakdown and disintegration of rock produce different minerals in to the soil. Clay mineral is also produced from different types of weathering and enriches soil quality in relation to agriculture productivity. On the summit and upper slope of the residual hill composed of rounded cubes of rocks fragments which are produced by deep mechanical weathering. Surface soil layer has been developed on the hard massive crystalline rock. Depth of the soil in the hill area is thin in character. Regolith results from detrital sediment. Sand and clay are produced from breakdown and disintegration of schistose rock through weathering and denudation processes. Alteration of feldspar and mica produces sandy clay particles of sand and silt also derived from quartz and other resistant mineral. This leads to porous, loose and granular soil character. Here soil is formed from the residual parent material. In contact with water feldspar become clay mineral with cations and anions in the solutions. Soil forming process of this area is also dominated by biological weathering. Organic acid produced from the decomposition of organic debris plays an important role to decomposition of rocks and minerals. Granite, gneiss, sand stone, conglomerate is playing an important role of parent material in the development of soil profile of this area. This patent material leads to the formation of soil texture like sandy loam that is existing over the whole area predominantly. Various sizes of pebble, gravel, pieces of conglomerate, granite, gneiss are present in the surface soil. Soil of this area is composed of those weathering generated particles. Here soil particle develops almost parallel to the surface. Sandy loam is principal soil texture of this area. This is formed by the siliceous types of parent material. Soil forming process moves faster in the foothill area than the escarpment area. Rate of soil development of this area is higher. Sand allows suitable situation for water percolation in the soil profile. Surface soil of this area has been developed on the hard massive crystalline rock. Depth of the soil in top of the hill and escarpment area is thin in character due to downward movement of soil forming materials. It goes toward down slope and gets accumulated in the foothill pediment area due to minimum slope and elevation. Surface soil are dry in character having about 1 to 2 percent soil moisture, but sometimes it varies up to 4 percent. Soil organic matter also ranges between .03 to 65 percent of total soil. Percentage of SOM is maximum in forest area and escarpment grass land. Soil $\mathrm{pH}$ is neutral in character. Maximum number of sample having salinity level 
of 30 to $45 \mu \mathrm{s} / \mathrm{cm}$ and some time it ranges between $30-90 \mu \mathrm{s} / \mathrm{cm}$. Status of nitrate nitrogen $(\mathrm{NN})$ in soil is very high when ammoniacal nitrogen (AN) is medium in character. High status of nitrogen $(\mathrm{N})$ in the soil leads to high rate of photosynthesis as well as growth of plant. Status of phosphorus (P) and potassium $(\mathrm{K})$ is very low in the soil. Dense forest is located at high elevated area. Escarpment area is associated with scattered vegetation and dry grassland. Forest and scattered vegetation are dominated by sandy loam soil texture, where hygroscopic moisture ranges between .26 to .056 percent. Soil $\mathrm{pH}$ varies neutral to slightly alkaline in character. Maximum salinity of soil occurs at the dense forest area. Because this area gets organic toxic from decomposition of organic compounds in contact to rain water. Dense forest located at the elevation of greater than $200 \mathrm{~m}$, where slope ranges between $10^{\circ}$ to $20^{\circ}$. Moderate forest located at elevation between 150 to $200 \mathrm{~m}$, where slope ranges between $10^{\circ}$ to $20^{\circ}$. Slope condition of dense and moderate forest remains same in association with identical pedological character. Soil organic matter remains high ( 1 - 3 percent) in the dense and moderate forest area. This area produces high organic matter, that is why soil $\mathrm{pH}$ ranges between neutral to slightly alkaline in character and level of salinity remains high. Scattered vegetation located at the elevation between $150 \mathrm{~m}$ to $200 \mathrm{~m}$ and greater than $300 \mathrm{~m}$ when slope is maximum $\left(20^{\circ}-40^{\circ}\right)$. This area is also associated with sandy loam soil texture with maximum concentration of organic matter ( 1 to 3 percent). Causes of high concentration of soil organic matter in surface soil of escarpment grass land area are it seasonal growth character and intensive root density. So it can produce maximum amount of organic debris to soil. Foot hill pediment area is associated with fallow land, current (agricultural) fallow and agricultural land at elevation of less than $200 \mathrm{~m}$ with less slope $\left(<5^{\circ}\right)$. Sometime scattered vegetation is found in fallow land of foothill area. This area is associated with sandy clay loam and clay loam soil texture. Clay mineral has been added into the soil of this area from the elevated area through overland flow. Soil organic matter of this area remains high ( 2 to 3 percent). Agricultural waste and scattered vegetation are the main source of organic debris into the soil of this area. Concentration of soil hygroscopic moisture into the soil of this area remains high (.30 - 1.94 percent). Because clay has capacity to hold water and store it into soil as moisture. Soil $\mathrm{pH}$ of foothill area is neutral in character. Concentration of soil salinity in foothill area remains normal.

\section{Conclusion}

Foothill area can become much resourceful with the help of proper land use planning and monitoring and weather forecasting. Rainfall prediction is very important for this area. Because rainfall is the main source of water for agriculture and natural vegetation in this hill area. According to slope and soil character, it is better to practice terrace cultivation method in foothill area for agriculture. Step cultivation can play a dual role. It can be check soil erosion and increase agricultural productivity in this area. Leguminous crops should be intro- 
duced in the foothill cultivation system to ensure the increase of soil moisture and valuable nutrients for plant growth into the soil. Afforestation and conservation of new plant are required in the hill region. Stabilization of slope is only possible with the growth of vegetation. It can also enrich soil depth and quality.

\section{Acknowledgements}

My sincere thanks are due to Dr. Sunando Bandyopadhyay, Professor \& Head, Department of Geography, University of Calcutta for his guidance during field studies. My sincere thanks is also due to Dr. Srikumar Chattopadhyay, Scientist, Centre for Earth Science Studies, Trivandrum. I am grateful to Prof. V. S. Kale, former Professor of Geography, University of Pune and Dr. Lakshmi Sivaramakrishnan, Professor \& Head, Department of Geography, Jadavpur University for their suggestions. I am very thankful to my research guide former Prof. Pannalal Das, Department of Geography, University of Calcutta for his motivation and suggestions.

\section{Conflicts of Interest}

The author declares no conflicts of interest regarding the publication of this paper.

\section{References}

Bandyopadhyay, S., Kar, N. S., Das, S., \& Sen, J. (2014). River Systems and Water Resources of West Bengal: A Review. https://doi.org/10.17491/cgsi/2014/62893

Bhattacharya, B. K., Chakraborty, B. R., Sen, N. N., Mukherji, S., Ray, P., Sengupta, S., Sengupta, K. S., Sen, N. N., \& Maity, T. (1985). West Bengal District Gazetteers: Puruliya. Kolkata: Government of West Bengal.

Brady, N. (1999). The Nature and Properties of Soils. Upper Saddle River, NJ: Prentice Hall.

Chatterjee, S. (2005). Pedogeomorphology of Some District of West Bengal with Application of Models. Unpublished PhD Thesis, Burdwan: The University of Burdwan.

Conacher, A. J., \& Dalrymple, J. B. (1977). The Nine-Unit Land Surface Model: An Approach to Pedogeomorphic Reaches. An International Journal of Soil Science, Geoderma, 18, 127-144. https://doi.org/10.1016/0016-7061(77)90087-8

Conacher, A. J., \& Dalrymple, J. B. (1978). Identification, Measurement and Interpretation of Some Pedogeomorphic Processes. Zeitschriftfur Geomorphologic, Supplement Band, 29, 1-9.

Das, T., Sarkar, D., Chattopadhyay, T., Dutta, D., Singh, D. S., Mukhopadhyay, S., Nayak, D. C., \& Banerjee, T. (2010). Soils of Puriliya District, West Bnegal for Optimizing Landuse. NBSS Publication Number 599, Naagpur: NBSS \& LUP.

Dasgupta, P. (2015). Rock Characteristics and Susceptibility to Weathering: A Study in the Metamorphic Terrain of Ajodhya Hill, West Bengal. Journal of Indian Geomorphology, 3, 27-47.

De, N. K. (1972). Measuring Soil and Landform Characteristics of Parts of Banka Basin, Burdwan. In Proceedings Symposium on Geomorphology, Geohydrology (pp. 46-58). Kharagpur: Geotectonic of the Lower Gang Basin IIT. 
De, N. K. (1984a). Pedogeomorphology. A Concept in Earth Science. Burdwan University Journal of Science, 1, 18-25.

De, N. K. (1984b). Measuring Land Potentials in Developing Countries. Burdwan: The University of Burdwan.

De, N. K. (1987). Application of Geomorphology in Soil Survey. Exploration in the Tropic, K.R. Dixit Felicitation Volume. Pune.

De, N. K., \& Chatterjee, S. (2009). Pedogeomorphological Model and Land Evolution, Geomorphology of India (Prof. Savindra Singh Felicitation Volume, pp. 547-563). Allahabad: PryagPustakBhavan.

De, N. K., \& Sarkar, H. K. (1993). Soil Geography. Kolkata: Sribhumi Publishing Company.

Dey, B., \& De, N. K. (1988). Pedogeomorphological Study in Lower Bengal Basin, India with Land MSS Data. Landscape System and Ecological Studies, 11, 110-120.

Gerrard, J. (1995). Soil Geomorphology, an Integration of Pedology and Geomorphology (pp. 29-50). London: Chapman \& Hall.

Ghosh, A. K. (2013). Status of Environment in West Bengal. Second Citizen Report, Kolkata: Society for Environment and Development.

Goudie, A. S. (2003). Encyclopedia of Geomorphology. London: Routledge Publication, Taylor and Francis Group.

GSI: Geological Survey of India (1999). Geology and Mineral Resources of the States of India, Pt. 1: West Bengal (Vol. 30).

Jenny, H. (1930). A Study on the Influence of Climate upon the Nitrogen and Organic Matter Content of the Soil (p. 152). Missouri Agricultural Experiment Station Res. Beet.

Jenny, H. (1941). Factors of Soil Formation. New York: McGraw-Hill Book Co. Inc. https://doi.org/10.1097/00010694-194111000-00009

Kaley, A. K. (2007). Soil Genesis, Classification Survey and Evolution (Vol. 1). New Delhi: Atlantic Publisher and Distributor.

Kumar, A. (1979). Geomorphology of Simdega and Its Adjoining Area, Bihar. Publication Number 22, Varanasi: The National Geographical Society of India, Banaras Hindu University.

Lahiri, R. (1964). The Geographical Background of the Soils of India. Geographical Review of India, 26, 13-20.

Lal, R. (2016). Encyclopedia of Soil Science (3rd ed.). Singapore: C\&C Press. https://doi.org/10.1081/E-ESS3

Mahapatra, G. B. (2008). A Text Book of Geology. Delhi: CBS Publishers and Distributers.

Mehera, R. K. (2006). Text Book of Soil Science. New Delhi: ICAR Publication.

Mollay, L. (1998). Soils in the New Zealand Landscape: The Living Mantle (p. 146). Lincoln: New Zealand Society of Soil Science.

O’Malley, L. S. S. (1999). Bengal District Gazetteers: SantalParganas. Kolkata: West Bengal District Gazetteers, Department of Higher Education, Government of West Bengal.

Sarkar, A., \& Das, P. (2018). Pedogeomorphology of the Plateau Fringe Region of Biharinath Hill, Bankura District of West Bengal and Its Influence on Landuse and Landcover. International Journal of Research and Analytical Reviews, 5, 488-501.

Selby, M. J. (1982). Hill Slope Material and Processes (pp. 152-165). Oxford: Oxford Uni- 
versity Press.

Slaymaker, O. S., \& Embleton-Hamann, C. (2009). Geomorphology and Global Environment Change. Cambridge: Cambridge University Press. https://doi.org/10.1017/CBO9780511627057

Sparks, B. W. (1986). Geomorphology (3rd ed.). London: Longman Scientific and Technical.

Steila, D. (1976). The Geography of Soil Formation Distribution and Management. Upper Saddle River, NJ: Prentice-Hall.

Strahler, A. N. (1973). Introduction to Physical Geography (3rd ed.). New York: John Wiley \& Sons.

Summerfield, M. A. (1991). Global Geomorphology, an Introduction to the Study of Land Forms (9th ed., pp. 163-184). London: Longman Scientific and Technical.

Tan, K. H. (2008). Soils in the Humid Tropics and Monsoon Region of Indonesia. Boca Raton, FL: CRC Press. https://doi.org/10.1201/9781420069105

Thomas, M. F. (1969). Geomorphology and Land Classification in Tropical Africa. In M. F. Thomas, \& G. T. Whittington (Eds.), Environment and Landuse in Africa (pp. 103-146). London: Methuen.

Thornbury, W. D. (1954). Principles of Geomorphology. New York: John Wiley. https://doi.org/10.1097/00010694-195408000-00023

Tricart, J. (1965). Principal Methods of Geomorphology. Paris: Masson.

Vats, P. C. (1988). Role of Geomorphology in Landuse and Rural Settlement Planning in the Arid Environment, Western Rajasthan. In S. Sing, \& R. C. Tiwari (Eds.), Geomorphology and Environment (PP. 566-580). Allahabad: The Allahabad Geographical Society.

Zinck, J. A. (2013). Geopedology (p. 1). ITC Special Lecture Notes Series.

Zinck, J. A., Metternicht, G., BoccoVerdinelli, G. H. R., \& Del Valle, H. F. (2016). Geopedology: An Integration of Geomorphology and Pedology for Soil and Landscape Studies. Berlin: Springer. https://doi.org/10.1007/978-3-319-19159-1

Zong, R. N. et al. (2012). Environmental Soil Properties and Behavior. Boca Raton, FL: CRC Press. 